University of Rhode Island

DigitalCommons@URI

Open Access Master's Theses

1989

\title{
The Relationship of Land Use and Groundwater Quality: A Case Study of Rhode Island
}

Xinhao Wang

University of Rhode Island

Follow this and additional works at: https://digitalcommons.uri.edu/theses

\section{Recommended Citation}

Wang, Xinhao, "The Relationship of Land Use and Groundwater Quality: A Case Study of Rhode Island" (1989). Open Access Master's Theses. Paper 660.

https://digitalcommons.uri.edu/theses/660

This Thesis is brought to you for free and open access by DigitalCommons@URI. It has been accepted for inclusion in Open Access Master's Theses by an authorized administrator of DigitalCommons@URI. For more information, please contact digitalcommons-group@uri.edu. 


\section{MASTER OF COMMUNITY PLANNING \\ RESEARCH PROJECT \\ OF}

XINHAO WANG

Approved:

$$
\text { Major Professor }
$$

$$
\text { John J. Rupa }
$$

Acknowledged:

$$
\text { Director }
$$

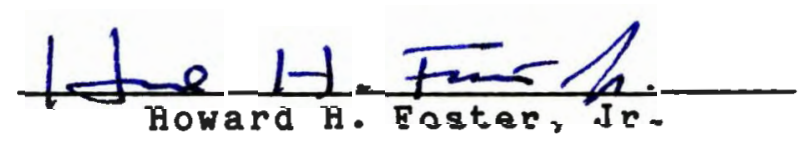




\begin{abstract}
THE RELATIONSHIP OF
LAND USE AND GROUNDWATER QUALITY:

A CASE STUDY OF RHODE ISLAND
\end{abstract}

BY

XINHAO WANG

A RESEARCH PROJECT SUBMITTED IN

PARTIAL FULFILLMENT OF THE REQUIREMENTS

FOR THE DEGRE OF MASTER OF

COMMUNITY PLANNING

UNIVERSITY OF RHODE ISLAND

1989 
The quality of groundwater used for drinking is critical to consumers. Due to the nature of groundwater flow, pollution source control is important for groundwater protection. Point and nonpoint pollution sources are closely related to land use. The pollution sources that originate from particular land uses must be identified and controlled to prevent degradation of groundwater quality.

This research is a study of the relationship between groundwater quality and land use in Rhode Island state. Water quality data were collected from twenty-one public drinking water wells and land use data were interpreted from air photos. Water quality data and land use data from 1970 and 1988 are compared to analyze the change of land use and change of groundwater quality.

The study areas are within a 1,000 foot radius around each well. Land use types include commercial/industrial, residential, undeveloped, and agricultural land. Road systems are also considered as a factor in this study. A computerized Geographic Information System (ARC/INFO) has been applied in the study. Several statistical methods have been used to analyze the relationship between land use and groundwater quality. 
The water quality data in 1988 indicate that nitrate and chloride do not pose a threat to groundwater in Rhode Island. However, sodium levels are likely to cause water quality problems at some public drinking water wells. The analysis demonstrates that the nitrate, chloride, and sodium concentrations in groundwater in 1988 were greater than that in 1970. This indicates that groundwater among the study wells has degraded over the study period.

The study determined that undeveloped areas around study wells decreased significantly from 1970 to 1988 . The result shows that most new development in these area had converted undeveloped land into residential, commercial, or industrial land.

The study has found that the areas of residential land use and surface water are related to increases in the levels of chloride and sodium concentrarions in the wells. Nitrate concentrations in the wells are closely related to Increased areas of residential land and paved light duty roads.

It can be concluded from the research that urbanization has an impact on groundwater quality. Attention should also be given to the area beyond the 1,000 foot limit. Further studies will need to include more independent varlables and more valuable findings are expected by increasing the sample slze. 


\section{ACKMOULBDGEMENT}

Special recognition and thanks are due to Dr. John J. Kupa, research advisor, who suggested this research and gave the writer valuable advices at every phase of the study and precious comments on this paper.

The writer is especialiy thankful to the project commettee members, Dr. Peter V. August and Dr. Author J. Gold, Department of Natural Resources Science, URI, and Dr. Howard H. Foster, Department of Community Planning and Area Development, URI, for their suggestions and corrections to this project.

The writer would like to thank Ms. Carol Baker, Environmental Data Center, URI, Mr. Ernie Panciera, Groundwater Division/RIDEM, Dr. Farhad Atash and Mr. Jonathan Stevens, Department of Community Planning and Area Development, URI, and Dr. Daniel Urish, Department of Civil Engineering, URI. The discussion with them and the information recelved from them have been most useful throughout this project.

Finally, the writer would like to thank people at Division of Water Supply/RIDOH and People at Division of Planning/RIDA. They provided me data necessary for this study. 
$\underline{\text { Page }}$

ACKNOWELEDGEMENTS

11

TABLE OF CONTENTS

111

LIST OF FIGURES

LIST OF MAPS

LIST OF TABLES

iv

$v$

$\mathbf{v} 1$

CHAPTER 1 .

INTRODUCTION

CHAPTER 2. GROUNHATER

2.1. Hydrologic Circulation

2.2. The Importance of Groundwater

2.3. Groundwater Resources in Rhode Island

2.4. Groundwater Pollution Sources

CHAPTER 3. GROUNDWATER QUALITY IN RHODE ISLAND 19

3.1. Data Sources

3.2. Sample Design

21

$3 \cdot 3$.

Existing Condition

22

3.4 .

Change of Groundwater Quality

28

CHAPTER 4 .

LAND USE AROUND THE SAMPLE WELLS

34

4.1 .

Definition of Related Terms

34

4.2. Concept of Contributing Area

of a Pumping Well

4.3. Identification of Contributing

Area of a Pumping Well

35

4.4 Land Use Type within Study Area

CHAPTER 5 .

GROUNDWATER QUALITY AND LAND USE

52

5.1. The Relationship of Groundwater Quality and Land Use

5.2. Relationship of Water Quality

Change and Land Use Change

52

61

CHAPTER 6 .

SUMMARY

64

REF ERENCES 


\section{LIST OF FIGURES}

$\underline{\text { Page }}$

2.1 Schematic Diagram of the Hydrologic Cycle Potential Sources of Groundwater Contamination 11

2.2

$2 \cdot 3$

Diagram Showing How Polluted Water Can Be Induced to Flow from a surface stream to a Pumping Well

2.4

Fertilizer Use Comparison

3.1 Change of Groundwater Quality 30

4.1 Diagram of a Pumped Well

4.2 Flow to a Well Penetrating a Confined Aquifer Having a Sloping Plane

Plezometric Surface

5.1 Casual Variables of Nitrate Concentrations

$\begin{array}{ll}5.2 & \text { Casual Variables of Chloride Concentrations } \\ 5.3 & \text { Casual Variables of Sodium Concentrations }\end{array}$

58

59

$5 \cdot 3$

Casual Variables of Sodium Concentrations

59 


\section{LIST OF MAPS}

$\underline{\text { Page }}$

$\begin{array}{llr}2.1 & \text { Groundwater Resources } & 10\end{array}$

3.1 Nitrate Concentrations of Sample Wells (1988) 25

3.2 Chloride Concentrations of Sample Wells (1988) 26

3.3 Sodium Concentrations of Sample Wells (1988) 27 
$\underline{\text { Page }}$

2.1 Distribution of Water Resources

3.1 Water Quality of Sample Wells

$3 \cdot 2$

Simple Correlation Coefficients of Water Quality Indicators in Sample Wells

4.1

$4 \cdot 2$

Factors Affecting the Contributing Area

Land Use Typies in Study Area (Whole Area)

38

$4 \cdot 3$

Land Use Typies in Study Area (Outwash Only)

47

4.4

T-Test Result of Land Use Type (Whole Area)

48

$4 \cdot 5$

T-Test Result of Land Use Type (Outwash Only)

51

5.1 Simple Correlation Coefficients of Water Quality and Land Use

$5 \cdot 2$ Correlation Analysis of Land Use Change and Water Quality Change 


\section{CHAPTER 1 INTRODUCTION}

The quality of groundwater used for drinking is critical to consumers. Due to the nature of groundwater flow, it is very difficult and possibly not practical to cleanse contaminated groundwater. Therefore, response to contamination incidents after they occur is not an adequate solution to the problem of groundwater pollution. Pollution source control is important for groundwater protection.

There are two major pollution sources affecting the quality of groundwater: Point sources and non-point sources. Point source pollution occurs when pollutants are discharged through a pipe such as from urban wastewater treatment plants and industries. Nonpoint source pollution usually originates from diverse sources, some undefined, and have no regular, predictable flow. Urban runoff and leachates from landfills are examples of nonpoint source poliution.

Both pollution sources are closely related to land use. The pollution sources that originate from particular land uses must be identified and controlled to prevent degradation of groundwater quality. It is a matter of considerable urgency to examine the relationship between land use and groundwater quality. 
Historically, agricultural land use and open space in Rhode Island have given way to residential, commercial, and industrial development. Tourism and in-migration with its associated commercial services are important segments of the state's economy and indicate increasing economic development and urbanization in the state (RIDEM/OEC 1988). A serious concern is how the urbanization effects the quality of groundwater in the state. This research project is a study of the relationship between water quality of selected public drinking water wells, and land use surrounding the wells, in the state of Rhode Island.

Chapter two will provide a broad background of hydrologic circulation, groundwater as a resource and the potential pollution sources of groundwater. Groundwater is an important portion of the earth's water resources. Human activities become more varied because of groundwater. However, pollutants generated by human activities are endangering the groundwater quality.

Chapter three will discuss the existing groundwater quality in the State of Rhode Island and the change of groundwater quality from 1970 to 1988. The analysis is based on data from twenty-one public drinking water wells. 
Chapter four will examine land use typies surrounding the sample wells within 1,000 foot radius. The writer will first clarify the concept of contributing area of a pumping well, then determine the study area for this research, and finally, identify and analyze the land use patterns within the study areas. A computerized Geographic Information System/(ARC/INFO) at the University of Rhode Island was applied for the study.

Based on the findings from the previous chapters, Chapter five will go further into the relationship between groundwater quality and land use type. Statistic techniques are used to identify the relationship.

Chapter six will summarize the research project and recommend further studies. This is a preliminary study of the factors of groundwater pollution. It is also an effort of applying GIS into groundwater protection and land use study. More valid findings are expected with studies in depth. 


\section{CHAPTER 2 GROUHDUATER}

2.1. Hydrologic Circulation

Hydrologic cycle refers to the circulation of water within the total earth system: atmosphere, hydrosphere, and 11thosphere. The atmosphere is the gaseous envelope above the hydrosphere. The hydrosphere consists of the water bodies which cover the surface of the earth. The lithosphere is the solid rock environment below the hydrosphere. Figure 2.1 lilustrates schematically this cycle.

The earth's hydrologic cycle has neither a beginning nor an end. However, it may be examined by looking at the cycle first as it takes place in the ocean. The energy of the sun's rays causes water to evaporate from the surface of the oceans into the atmosphere. The evaporated water rises, then collects to form clouds. Under certain conditions the cloud moisture condenses and falls back as precipitation to the earth either on land or in the oceans. The precipitated water may be intercepted or transpired by plants, may run over the ground surface to streams, or may soak into the soll. 
Figure 2.1 Schematic Diagram of the Hydrologic Cycle

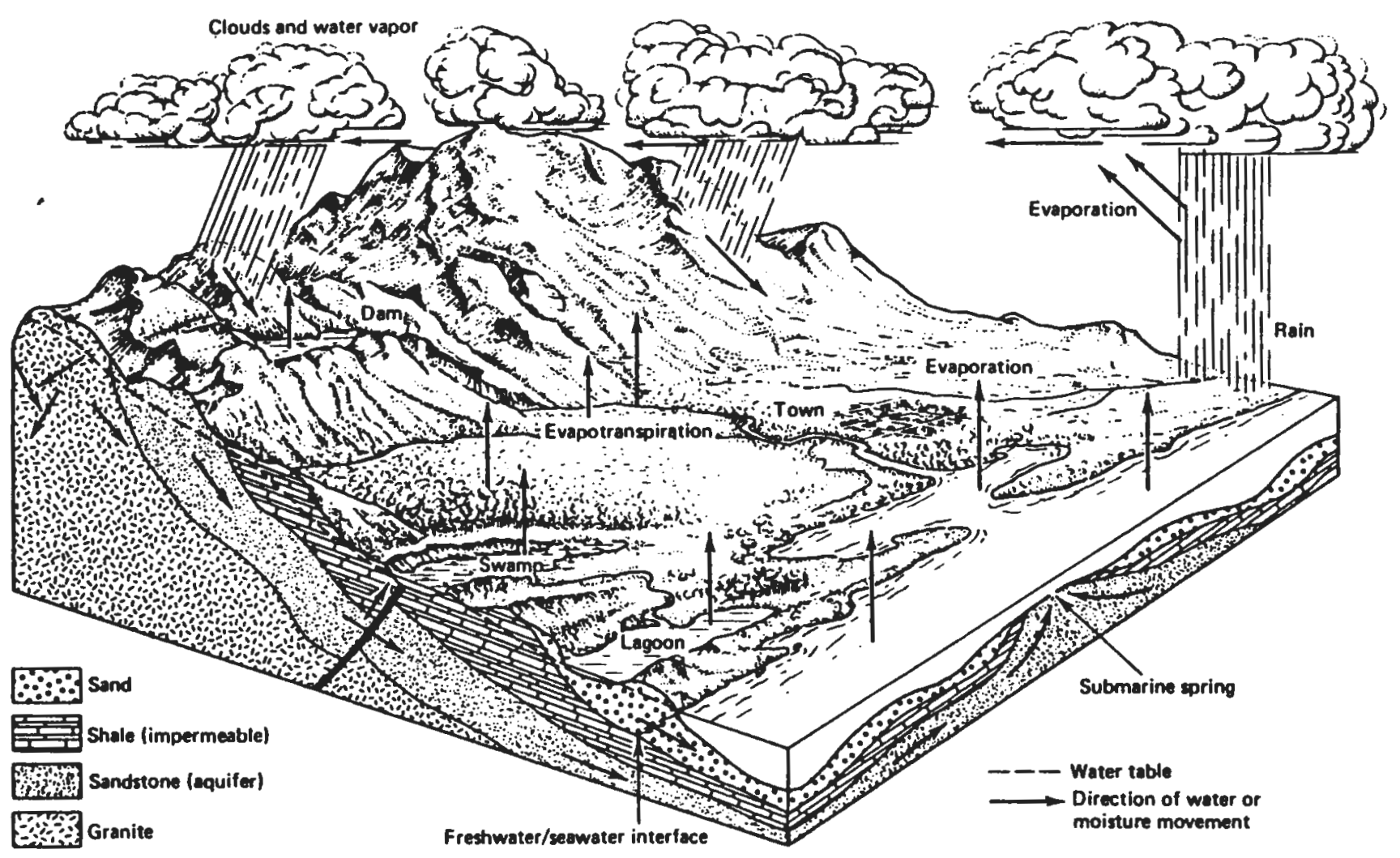

Source: Todd 1980 
Much of the intercepted and transpired water, some surface runoff, and the water detained in the plant root zone return to the air through evaporation and transpiration. Some of the water that enters the soil may percolate downward to be stored as groundwater. Groundwater moves through numerous open spaces of subsurface materials and flows out of rocks, as springs or seeps, into streams. The streams carrying both surface runoff and natural ground water discharge, eventually lead back to the oceans to complete the hydrologic cycle.

The hydrologic cycle is a system by which nature circulates water from the oceans through the atmosphere and returns it both overland and underground back to the seas.

\subsection{The Importance of Groundwater}

Groundwater constitutes one portion of the hydrologic cycle. Research has revealed that groundwater is one of the earth's most widely distributed and most important resources.

Table 2.1 gives the distribution of water in different forms. Among the earth's total water resources, 97.2 percent rests in the oceans and seas. Because of the high levels of salinity, the ocean water cannot be used for drinking without expensive desalinization. Another 2.15 
percent is kept in glaciers and lcecaps and is hardly useful. Only 0.0101 percent of water occurs in reservoirs, streams, and lakes as fresh water resources.

\begin{tabular}{ll} 
Table 2.1 & Distribution of Water Resources \\
\hline Ocean & $97.20 \%$ \\
Glaciers and icecaps & $2.15 \%$ \\
Reservoirs and lakes & $0.01 \%$ \\
Streams & $0.0001 \%$ \\
Groundwater (depth $<2,600 \mathrm{ft}$ ) & $0.30 \%$ \\
Groundwater (depth $>2,600 \mathrm{ft})$ & $0.30 \%$ \\
Water vapor in atmosphere & $0.001 \%$ \\
Soil moisture in top $0.6 \mathrm{~m}$ & $0.002 \%$
\end{tabular}

Source: Raghunath 1987 p.457.

The groundwater storage accounts for 0.6 percent of total water resources and half of it remains within a depth of 2,600 feet or less, which can be economically extracted with the present drilling technology (Raghunath 1987). Among the available water resources, groundwater storage is about thirty times more than that from streams and lakes. Groundwater provides water supply to industries, agriculture, municipalities and many other consumers. People use groundwater because of its convenient availability near the point of use, its excellent quality, and 1ts relatively low cost of development (Todd 1980). Groundwater constitutes the major sources of drinking water for half the population of the United States. 
2.3. Groundwater Resources in Rhode Island

Groundwater is a locally abundant and widely used resource in Rhode Island. Fifty-one percent of groundwater withdrawals are for public water supply (Johnston, 1985), which provides drinking water to twenty-five percent of the state's population (Concern (a) 1988).

Rhode Island is in the New England Upland and Seaboard Lowland Sections of the New England physiographic province and in the Glaciated Appalachian groundwater region (Fenneman 1938). The major source of groundwater is precipitation. The average annual precipitation ranges from forty-two inches to forty-eight inches.

In Rhode Island, groundwater mainly occurs under unconfined conditions. Stratified drift underlies about one-third of the state. Glacial drift consists of fine to coarse rock materials. Till is a type of unsorted deposits, which consist of a heterogeneous mixture of materials that were deposited directly by a glacier. Till is usually very dense and relatively impermeable so that it does not yield large quantities of groundwater. It is estimated that approximately eight to nine inches of precipitation recharges groundwater in the areas of t111 (Johnston 1985). Stratified drift, or outwash, was deposited by glacial meltwater and is generally uniform and well-sorted. About 
teenty-one to twenty-five inches of precipitation recharges groundwater in the areas of stratified drift (Johnston $1985)$

The most productive aquifers are composed of saturated, coarse-grained, stratified drift deposits. These aquifers are capable of sustaining large quantities of groundwater withdrawals for municipal and industrial supplies. The state contains twenty-one major groundwater aquifers within four of its river basins - Narragansett Bay, Blackstone, Pawtuxet, and Pawcatuck Rivers (Map 2.1).

\subsection{Groundwater Pollution Sources}

In the natural hydrologic cycle, human activities have induced many negative effects on the quality of groundwater. Groundwater pollution may be defined as the artificial degradation of natural groundwater quality. Pollution can impair the use of water and can create hazards to public health. Compared with surface water pollution, groundwater pollution is difficult to detect, and is even more difficult to control. The intensive use of natural resources and the large production of wastes in modern society often pose a threat to groundwater quality and have already resulted in many incidents of groundwater contamination. 
Map 2.1 Groundwater Resources

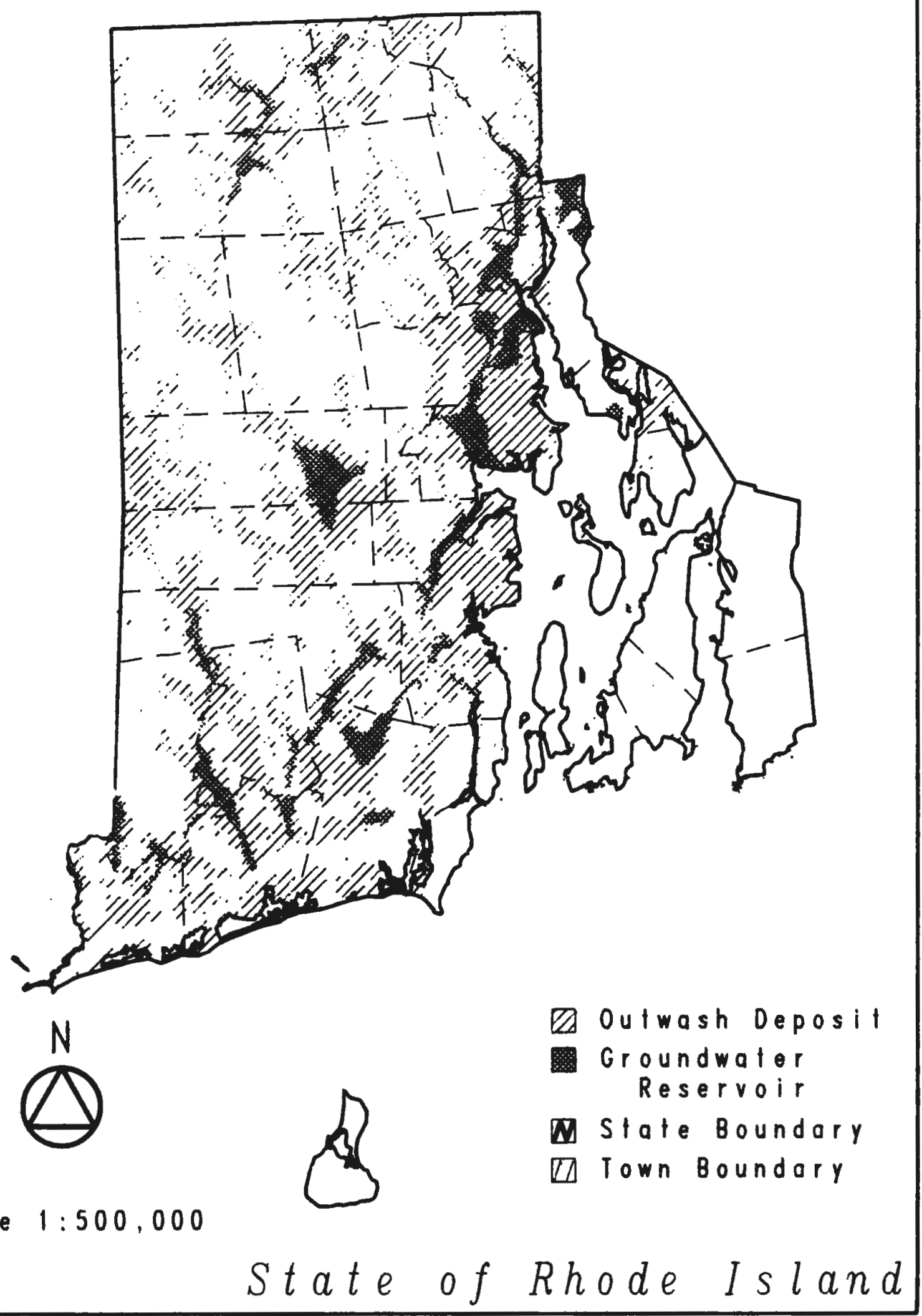


Figure 2.2 shows the potential pollution sources and the paths of pollutants getting into groundwater. The major water pollution problems are related to the density and distribution of development. Pollutants from various sources come into groundwater through the water flow. As development proceeds, the quantity of these pollutants in Broundwater reaches levels that make the water unpalatable, undrinkable, and sometimes toxic.

EIgure 2.2 Potential Sources of Groundwater Contamination

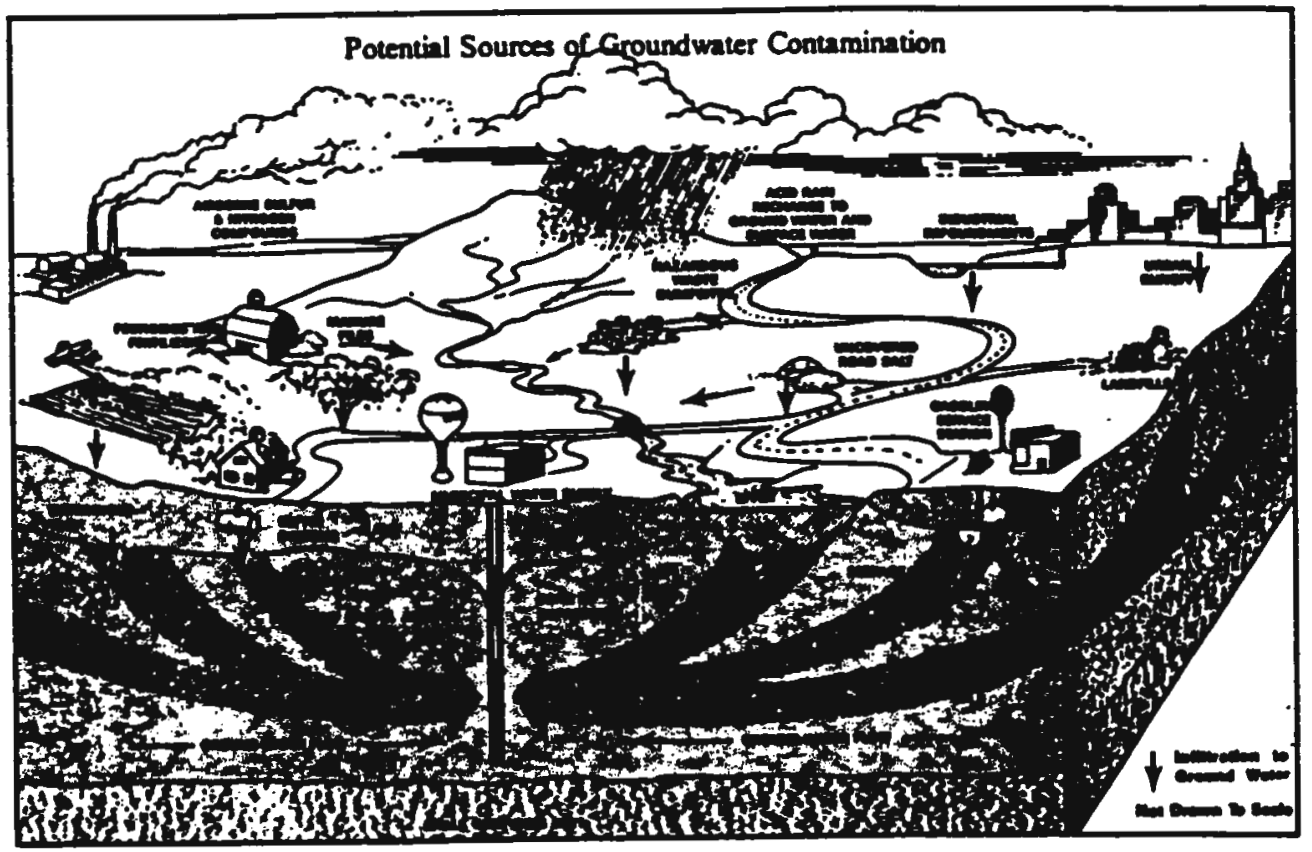

Source: Concern (b) 1988 
2.4.1. Industry

Certain common industrial operations, such as mining, drilling, construction, and forestry can contaminate water as part of their normal activities. The disposal of Industrial waste into landfills, pits, lagoons, deep injection wells, and dumps has caused widespread contamination of drinking water sources (Concern (a) 1988).

\subsubsection{Agriculture}

Modern agriculture is based on extensive use of fertilizer and pesticides to obtain high crop yields. Repeated harvesting, planting, and application of fertilizers and pesticides can result in water quality impacts from erosion and sedimentation, contaminated storm water runoff, and contaminated leachate. When fertilizers are applied to farm land, a portion usually moves down through the soil to the water table. Nitrogen is a primary fertilizer pollutant and is only partially used by plants or absorbed by soils. Other primary fertilizers are compounds of phosphorus and potassium. Manure piles, feedlots and similar concentrations of animal wastes may also transport salts, organic loads, and bacteria into soil. 
Rhode Island's agriculture consists of both turf and crop production (corn, small grains, vegetables, and fruit), as well as livestock production (dalry, beef, hogs, and poultry). Agriculture is a significant nonpoint source problem in some specific areas, and to particular water bodies (RIDEM/OEC 1988). The studies of erosion and sedimentation, contaminated runoff, and soll loss indicate that management of erosion and sedimentation, and waste management controls on farm lands will be necessary in order for certain watersheds to achieve their designated water quality standards (Myers 1988).

\subsubsection{Road Deicing Practices}

Salt applied to snow- or ice-covered roads is a source of chloride and sodium to groundwater. Chloride levels in road runoff during snow melt have been observed to range from 1,130 to $25,000 \mathrm{mg} / \mathrm{l}$ (Bouwer 1978). Salt contaminated road runoff can infiltrate into the ground and seriously contaminate groundwater.

In an effort to provide for safe winter travel, Rhode Island Department of Transportation adopted a "bare pavement policy" in the 1960s. The application rate for road salt is usually on the order of 150 - 300 pounds per lane per mile per storm and greater quantities may be applied depending on the nature of the storm and the road 
being serviced (RIDEM/OEC 1988). It has been found that, due to the high solubility of chloride, virtually all

chloride applied to surface areas enters surface or groundwater. Many cases have been reported that percolation from improper storage and handing of road salt at storage facilities increased the local concentrations of sodium and chloride.

2.4.4. Serage

Sewage enters groundwater from septic tanks, cesspools, leakage from sewers and seepage from sewage lagoons. The rapid residential development in rural and suburban areas has produced an almost explosive increase in the number of homes served by septic tanks, which are now the most numerous and widely distributed potential sources of groundwater pollution in the United States. Much of the recent housing development in Rhode Island's rural areas is serviced by an Individual Sewage Disposal System (ISDS). The most recent data show that there are some 143,900 ISDS servicing slightly more than one-third of the state's population (RIDEM/OEC 1988).

The septic tank effluent contains relatively large concentrations of nutrients (primarily nitrogen and phosphorus), suspended solids, 011, grease, pathogens, and toxic chemicals. The effluent of septic tanks is 
infiltrated into the soil through a drain field. The most readily detectable effects of septic tank drainage on groundwater are increases in nitrate, chloride, and bacteria. The average flow of septic tanks is from 0.15 to 0.3 cubic meters per person per day (Bouwer 1978). The average septic tank effluent contains $40 \mathrm{mg} / \mathrm{l}$ of total nitrogen and almost inevitably causes localized groundwater contamination (RIDEM/OEC 1988). ISDS systems are suspected of contributing large quantities of nitrate to groundwater. Septic tanks present an insidious threat to groundwater because of their location in populated areas.

Sanitary sewers are another source of nonpoint pollution. Sanitary sewers are intended to be water tight but, in reality, leakage of sewage into the ground is a common occurrence. Sewer leakage can introduce high concentrations of BOD, COD, nitrate, organic chemicals, and possibly bacteria into groundwater.

\subsubsection{Urban Runorf and Polluted Surrace yater}

As the imperviousness of a site increases with the construction of buildings and paved areas, the volume and peak rate of runoff from the given site increases. The runoff may carry pollutants formerly bound on the ground into waterways. Runoff from roadways, parking lots, and urban development can contain nutrients, heavy metals, 
hydrocarbons, 011 and grease, pestic1des, pathogens, litter, and delcing salts, inorganic chemicals, petroleum products, and animal yeasts. The chemical composition of urban runoff depends on the land use and rainfall characteristics.

Many streams receive municipal and 1ndustrial wastewater and runoff. Seepage of such water into groundwater may adversely affect groundwater quality. The surface water recharge to groundwater may be lncluded by a pumping well, as Indicated In F1gure 2.3 (Todd 1980).

F1gure 2.3 Diagram Showlng How Polluted Hater Can Be Induced to Flow from a Surface Stream to a Pumping Hell

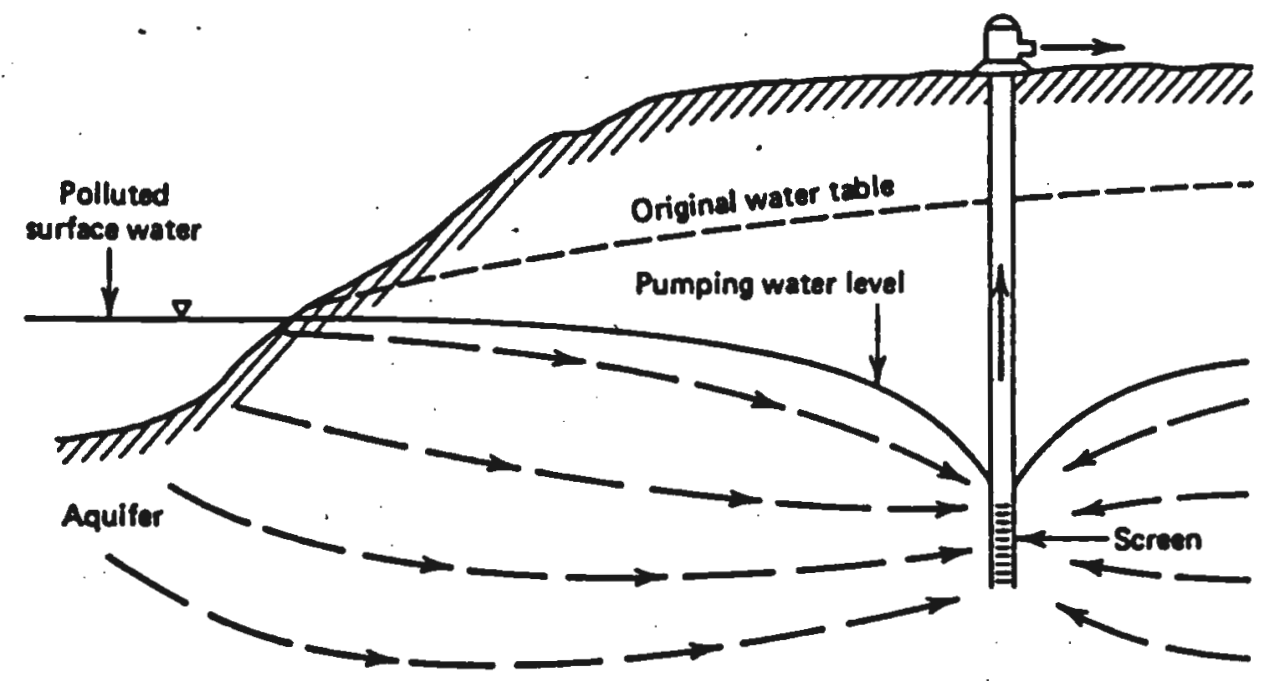

Source: Todd 1980 . 
$2.4 .6 . \quad$ Land 111

Many wastes of animal, municipal, industrial, or agricultural origin are applied on the land for disposal purposes, which leach into groundwater. The interest in utilizing land as a terminal recelver for disposal of wastes has focused considerable attention on the potential pollution source contributions from such land application sites.

\subsubsection{Municipal and Household Letivities}

Groundwater quality is threatened by miscallaneous municipal and household activities. Underground storage tanks present a threat to groundwater because of their propensity to leak. Pesticide and fertilizer contamination of water is not limited to agriculture. Spraying of pesticides and herbicides in parks, trees, golf courses, and along roads and rights-of-way is common. This is frequently done routinely without consideration of actual need or potential impact on groundwater.

The use and improper disposal of household cleansers, automotive products, and lawn and garden products may also cause groundwater pollution. 
With the Increasing urbanization in Rhode Island, the amounts of fertilizers and pesticides applied to home lawns have become a significant concern. Data show an increase of fertilizer use in Rhode Island from roughly 13,000 tons/year in 1980 to over 20,000 tons/year in 1986. However, farm type fertilizer usage constituted less than 2,000 tons/year in 1986 (F1gure 2.4).

Pigure 2.4 Fertilizer Use Comparison Farm Use vs. Home Use

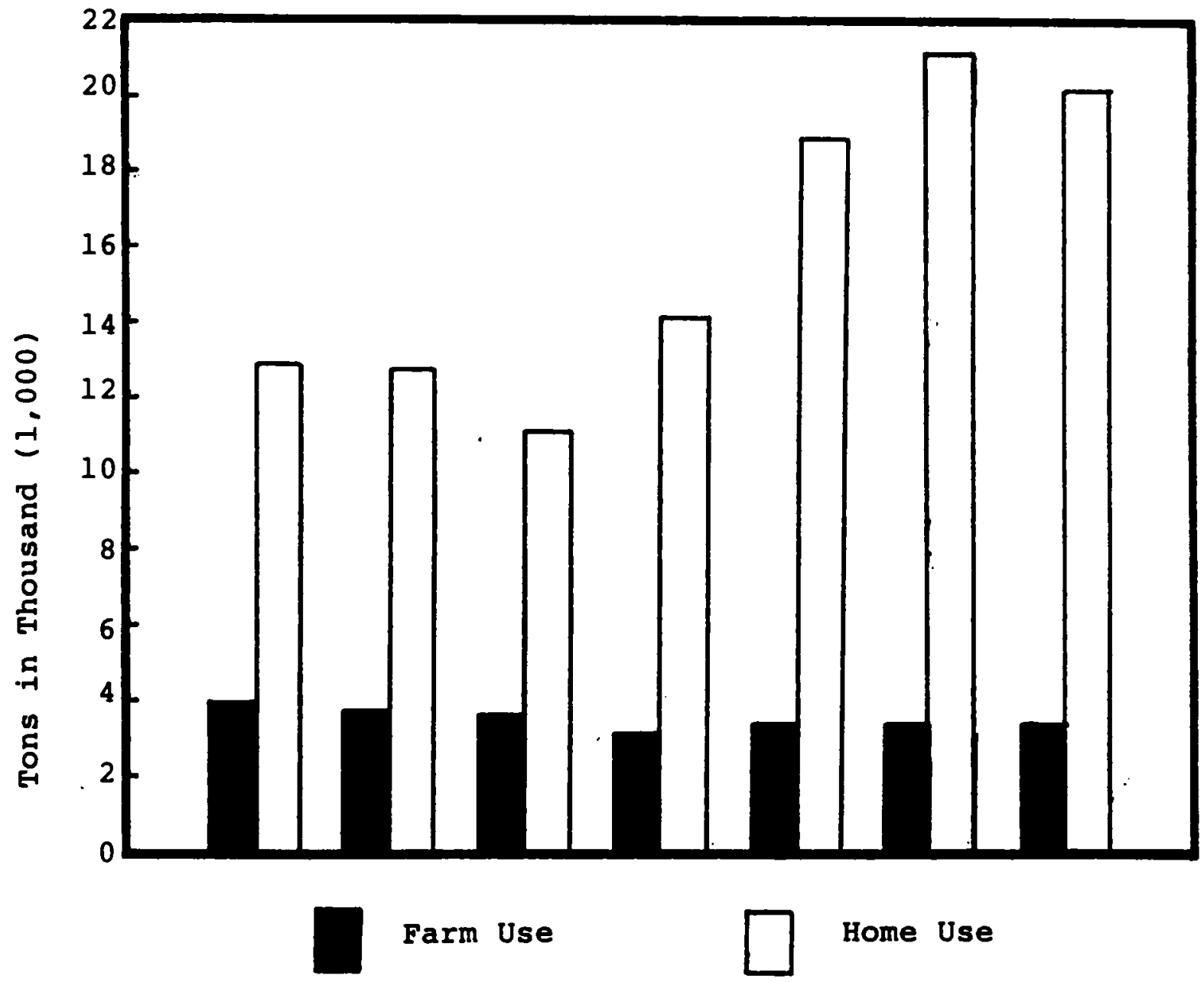

Source: RIDBM/OBC 1988 


\section{CHAPTBR 3 GROOHDUATBR QUALITI IR RHODB ISLARD}

Groundwater is a limited natural resource that is crucial to society. Drinking water supply is determined by water storage and water quality. Recently, many studies have reported the degradation of groundwater quality. Several public water systems which formerly relied on groundwater, in whole or in part, as a supply source, have switched to reliance on surface water supplies due to increasing problems with contamination (Concern (a) 1988). As of February 1986, nine public water system wells in Rhode Island had to be taken out of service because of groundwater contamination (RIOSP 1986).

This project is designed to identify the existing groundwater quality and the change of groundwater quality in Rhode Island in selected study wells from 1970 to 1988. Three indicators, nitrate, chloride, and sodium, have been considered. These indicators can best represent the influence of land use on groundwater quality. They are also considered mobile and conservative constituents.

The analysis is conducted based on data from twenty-one public drinking water wells. The study first determines the groundwater quality status by comparing the actual nitrate, chloride, and sodium concentrations with RIDEM standards of recommended level for the three indicators. 
Second, by comparing the concentrations in 1970 and that in 1988, the study further resolves whether the indicators manifest groundwater degradation in the eighteen years period.

\section{1 Data sources}

The Rhode Island Department of Health (RIDOH) is required by statute (RI General Laws, 46-13-1. et.seq.) to ensure the quality of water delivered by public-supply systems, which includes all supplies having at least fifteen service connections that regularly serve twenty-five or more people for sixty days or more during a year. More than 400 such systems are in service, most supplied by groundwater (Johnston 1985). The RIDOH is also authorized (RI General Laws, 46-14-1. et.seq.) to order abatement of pollution that poses a threat to a public supply.

The Division of Drinking Water Quality of RIDOH publishes annual reports of chemical analyses of public drinking water systems for the state. The water quality data for this study were collected from annual reports of the Division.

The Department of Environmental Management of Rhode Island (RIDEM) is involved in groundwater protection. RIDEM has located and mapped about 190 public drinking water wells. 
These data are stored in the ARC/INFO, a geographic information system/(GIS) at the Environmental Data Center of the University of Rhode Island.

\subsection{Sampling Design}

The selection of sample wells was limited by the data available for both water quality and well location information. Although Rhode Island Department of Environmental Management has location information for about 190 public drinking water wells and the annual reports of Rhode Island Department of Health provide water quality data of over hundred wells. Only twenty-eight wells, however, possess location information and water quality information for both 1970 and 1988. This is because some wells started operation after 1970 and, that some wells stopped operation before 1988 and, that some well names used by RIDEM and the names used by RIDOH are not consistent.

Furthermore, among the twenty-eight wells, seven pairs were located less than 1,000 feet from each other. Seven wells were dropped randomly because of the requirement of land use study. As a result, the sample population consisted of twenty-one wells. 
In spite of the small sample size, the twenty-one wells are located in more than ten different groundwater reservolrs. The nitrate, chloride and sodium concentrations from the sample wells also represent the three possible change: Increase, decrease, and stable.

\subsection{Existing Condition}

Table 3.1 shows the annual average water quality data of the twenty-one sample wells for 1970 and 1988. The Rhode Island Department of Environmental Management has set standards for contaminants in drinking water which may pose a health hazard. The standard for nitrate $1 \mathrm{~s} 10 \mathrm{mg} / \mathrm{l}$ and for chloride is $250 \mathrm{mg} / \mathrm{l}$. Although there is no standard for sodium, the RIDEM has recommended a maximum sodium concentration in drinking water of $20 \mathrm{mg} / \mathrm{l}$.

The highest nitrate concentration was observed in well 96 in 1988. The level reported was $4.7 \mathrm{mg} / \mathrm{l}$ or nearly one half of the RIDEM standard. The 1988 nitrate concentrations from twelve wells were below $2.0 \mathrm{mg} / \mathrm{l}$. The chloride concentration observed from well 120 was 77.0 mg/l. This is about three tenth of the RIDEM standard and is the highest level noted from the twenty-one wells for both 1970 and 1988 . These data indicate that nitrate and chloride in the study wells do not pose a threat to public wealth. 
Table 3.1 Water Quality of Sample Wells

\begin{tabular}{|c|c|c|c|c|c|c|c|c|}
\hline \multirow[b]{2}{*}{ Well name } & & \multirow[b]{2}{*}{ Well \# } & \multicolumn{2}{|c|}{$\begin{array}{l}\text { Nirtate } \\
(\mathrm{mg} / 1)\end{array}$} & \multicolumn{2}{|c|}{$\begin{array}{c}\text { Chloride } \\
(\mathrm{mg} / \mathrm{l})\end{array}$} & \multicolumn{2}{|c|}{$\begin{array}{l}\text { Sodium } \\
(\mathrm{mg} / 1)\end{array}$} \\
\hline & & & 1970 & 1988 & 1970 & 1988 & 1970 & 1988 \\
\hline aumberland-Town of & Manville \#1 & 89 & 0.60 & 1.20 & 27.00 & 45.00 & 18.40 & 24.70 \\
\hline Glendale-Davis & Well \#1 & 3 & 0.60 & 2.40 & 6.00 & 6.00 & 8.80 & 6.30 \\
\hline Harr isville Fire Dist & Well \#2 & 93 & 0.40 & 2.60 & 11.00 & 28.00 & 6.00 & 15.70 \\
\hline Kent county & Well \#1-Warw. & 95 & 0.30 & 1.40 & 22.00 & 28.00 & 12.00 & 15.30 \\
\hline Water Auth. & Sprg. Lake Well & 96 & 2.00 & 4.70 & 11.00 & 28.00 & 7.90 & 16.80 \\
\hline & Mishnock \#2 & 98 & 0.10 & 0.30 & 49.00 & 13.00 & 17.20 & 6.90 \\
\hline Kingston Fire Dist & Well \#1 & 99 & 1.30 & 4.10 & 22.00 & 24.90 & 11.40 & 12.90 \\
\hline Iadd School & Well \#1 & 101 & 1.20 & 2.50 & 22.00 & 14.00 & 10.90 & 9.60 \\
\hline & Well \#2 & 102 & 0.10 & 0.50 & 6.00 & 5.00 & 4.70 & 4.30 \\
\hline Mohegan Water Assn. & Well \#1 & 104 & 0.01 & 0.09 & 6.00 & 52.90 & 9.50 & 29.10 \\
\hline North Kingstown-Town & Well 1 & 106 & 0.30 & 0.60 & 19.00 & 35.00 & 11.90 & 20.30 \\
\hline & Well \#3 & 108 & 0.10 & 0.10 & 14.00 & 28.00 & 9.80 & 11.50 \\
\hline & Well \#4 & 109 & 2.00 & 2.10 & 15.00 & 14.00 & 7.80 & 7.80 \\
\hline Oakland Water Assn. & Tap & 120 & 0.70 & 1.80 & 35.00 & 77.00 & 17.00 & 44.40 \\
\hline Pascoag Fire & Well 2 & 121 & 1.80 & 0.90 & 19.00 & 15.00 & 12.40 & 10.30 \\
\hline Shady Harbor Fire Dist & twell \#3 & 142 & 0.30 & 0.90 & 10.00 & 9.00 & 7.70 & 7.60 \\
\hline North Smithfield-Town & Dug Well & 20 & 0.50 & 1.10 & 62.00 & 76.00 & 35.70 & 53.90 \\
\hline University of RI & Well \#3 & 153 & 0.70 & 2.20 & 11.00 & 15.00 & 7.70 & 10.10 \\
\hline Wakefield Water $c o$. & Well \#4 & 157 & 0.10 & 2.60 & 7.00 & 9.00 & 5.10 & 5.10 \\
\hline & Well \#5 & 158 & 3.50 & 2.80 & 16.00 & 12.00 & 8.90 & 6.90 \\
\hline Westerly- Town of & Well \#3 & 166 & 0.50 & 0.40 & 12.00 & 16.00 & 10.60 & 12.10 \\
\hline
\end{tabular}


The sodium concentration data for the sample wells show different result. In 1970, water in one well (well 20) had $35.7 \mathrm{mg} / \mathrm{l}$ sodium, which was $15.7 \mathrm{mg} / \mathrm{l}$ higher than the 20 mg/l RIDEM recommended maximum concentration. In 1988, well 20 still had the highest concentration, which was 53.9 $\mathrm{mg} / \mathrm{l}$ and the sodium concentrations from five wells were greater than the $20 \mathrm{mg} / \mathrm{l}$ level. The figures infer that sodium contamination of public drinking water wells in Rhode Island poses increased levels of concern among selected wells and aquifers.

Maps $3.1,3.2$ and 3.3 show location of sample wells. Each map displays the sample wells in four groups according to the 1988 nitrate, chloride, and sodium concentrations. The maps indicate that wells with high nitrate concentration may not have high chloride or sodium concentration and vice versa. The wells which have high chloride concentration most likely have high sodium concentration.

Table 3.2 gives simple correlation coefficients between nitrate and chloride, between nitrate and sodium, and between chloride and sodium. The results clearly indicate that there is no correlation between nitrate concentration and chloride concentration, neither between nitrate concentration and sodium concentration. However, the chloride concentration and sodium concentration are highly related. 
Map 3.1 Nitrate Concentrations of Sample Wells (1988)

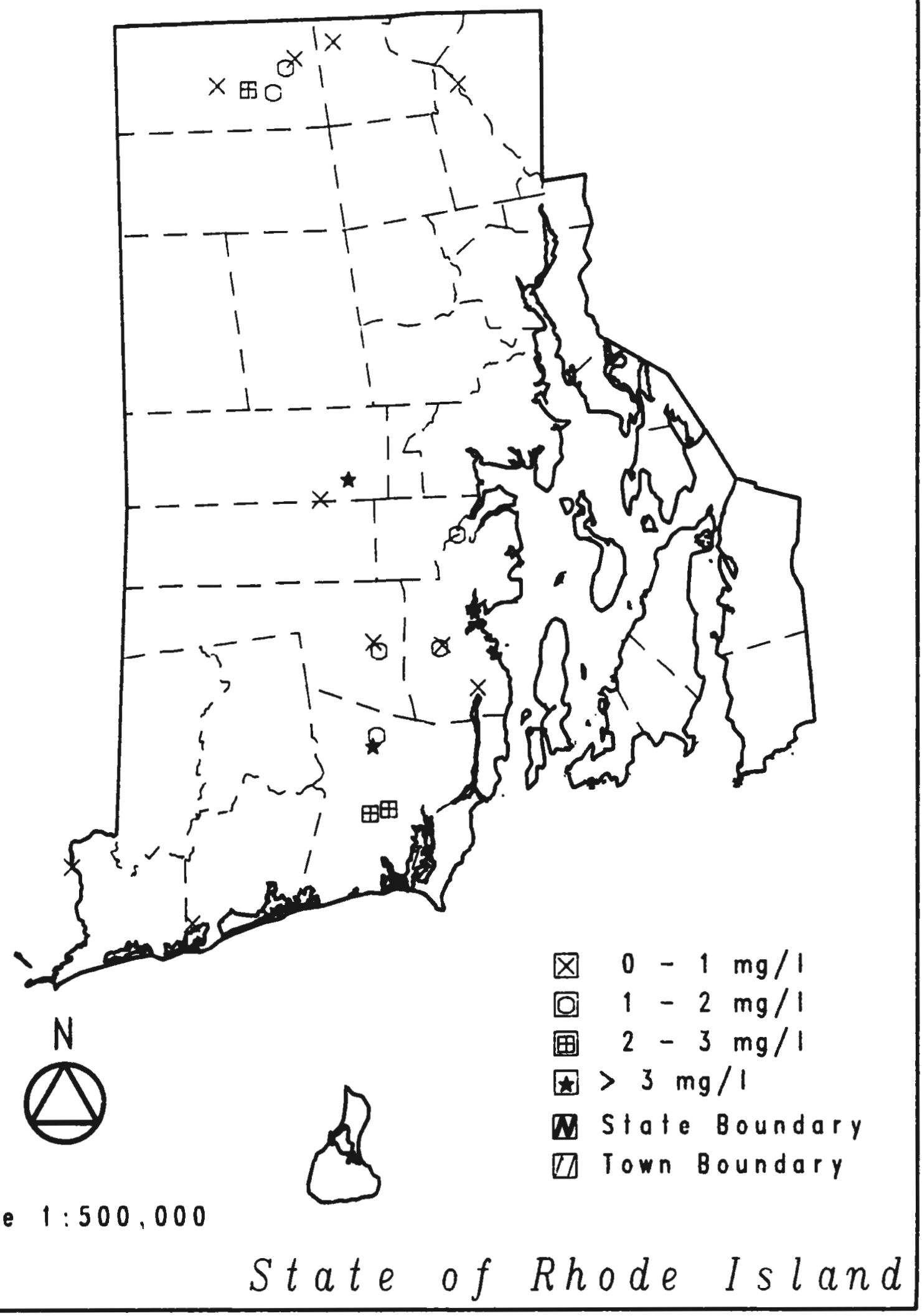


Map 3.2 Chloride Concentrations of Sample Wells (1988)

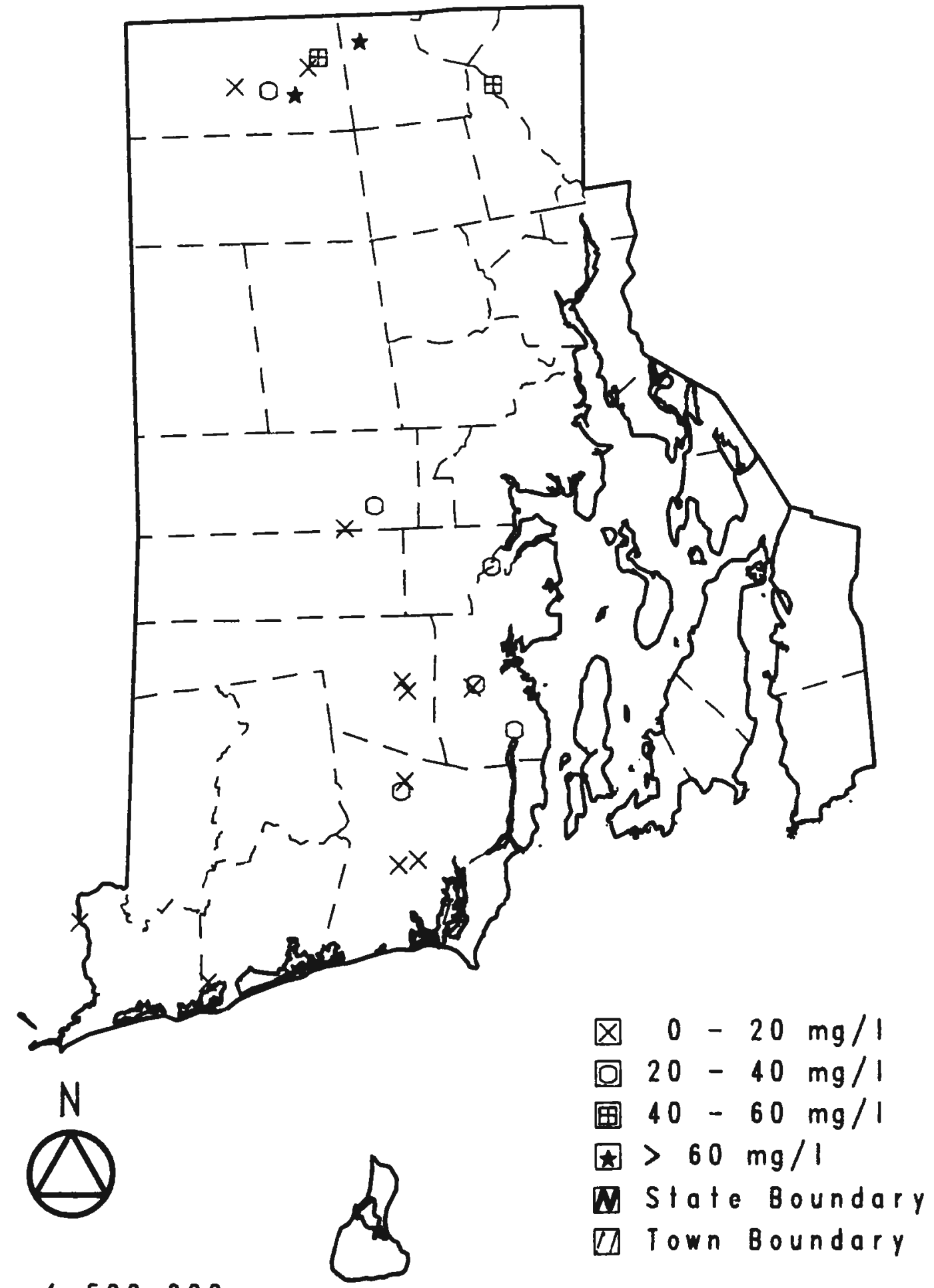

Scale 1:500,000

State of Rhode Island 
MAP 3.3 Sodium Concentrations of Somple Wells (1988)

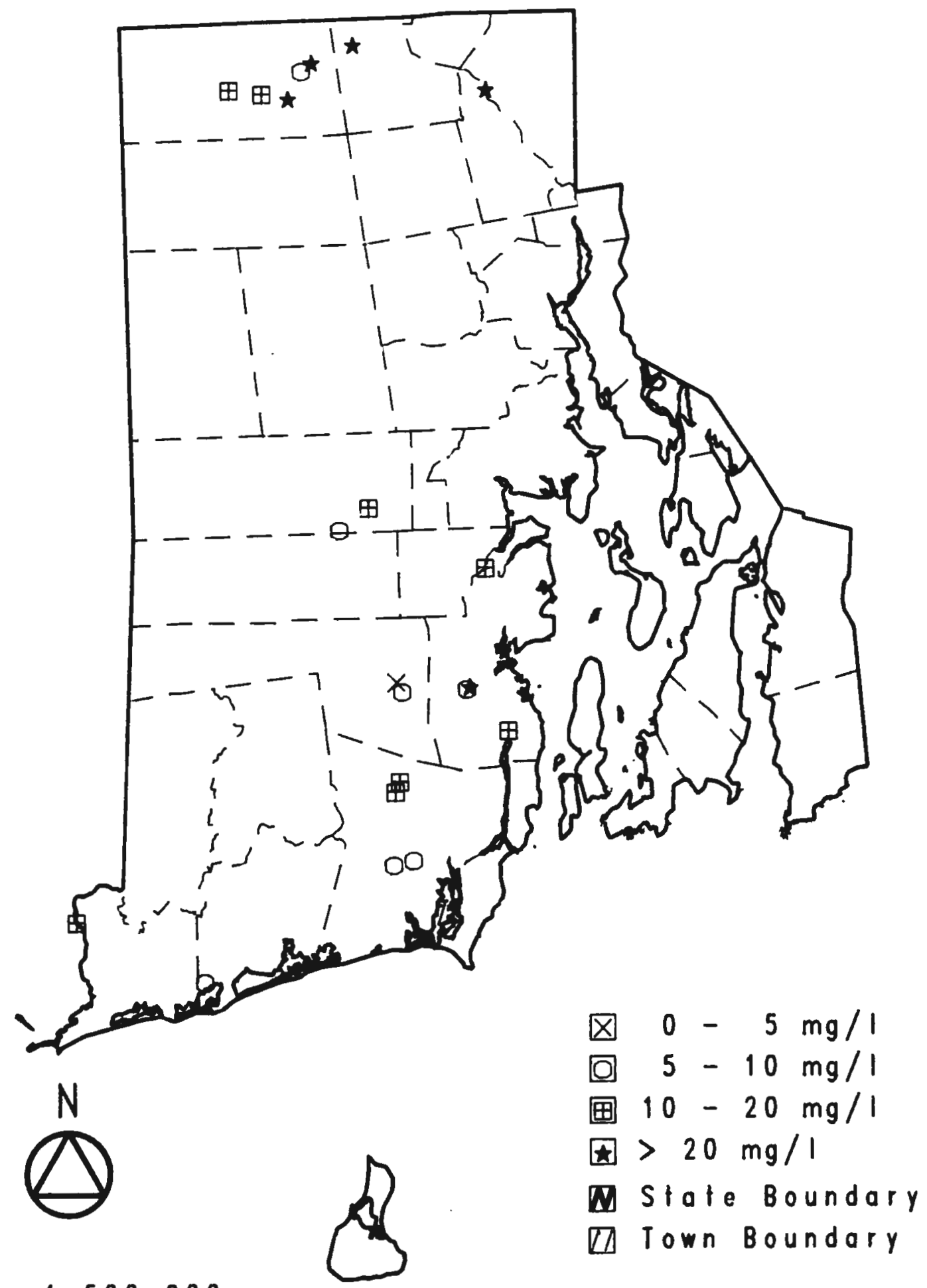

Scale $1: 500,000$

State of Rhode Island 
Table 3.2 Simple Correlation Coefficients of Water Quality Indicators in Sample Wells

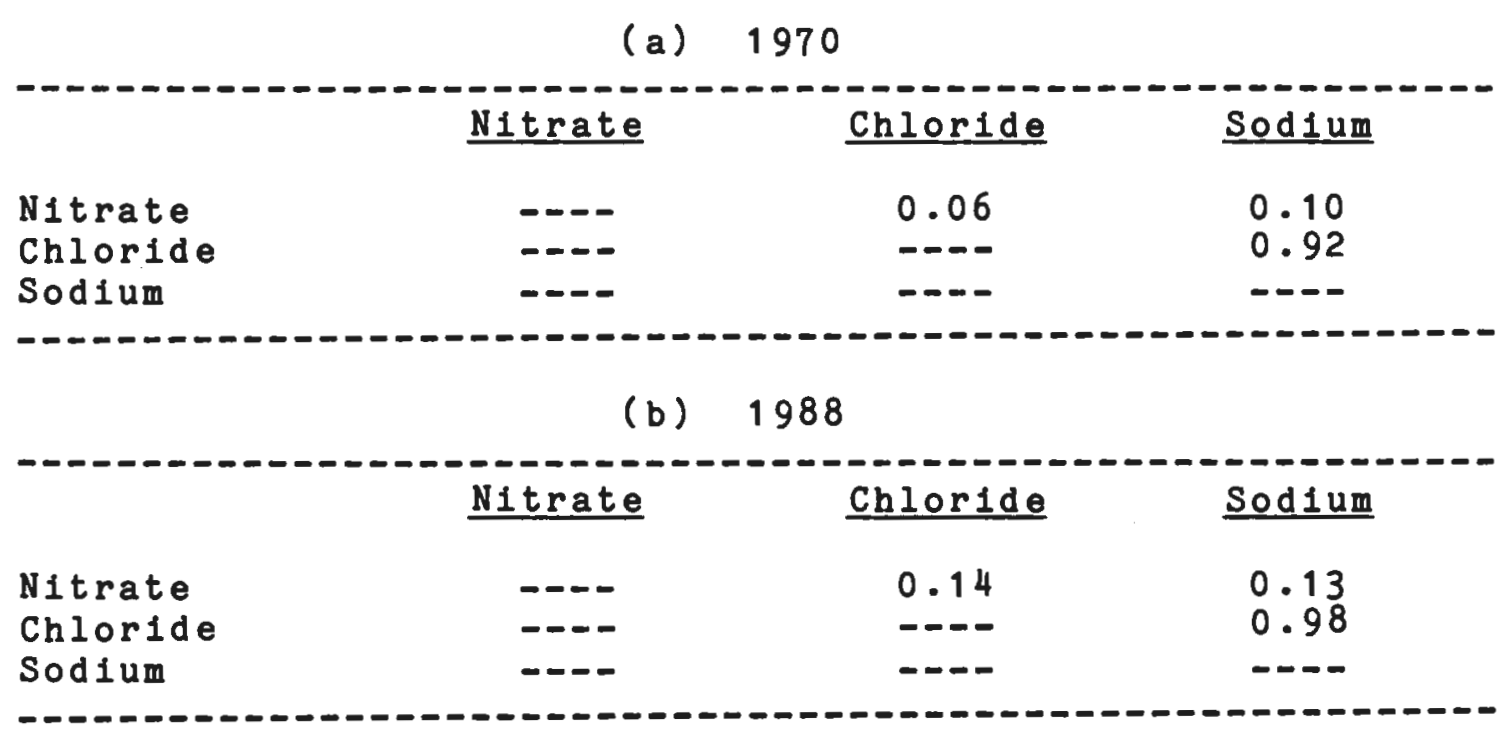

The data imply that the sources contributing nitrate to groundwater may be different from the sources contributing chloride or sodium, and that chloride and sodium in groundwater may come from similar sources.

3.4. Change of Groundwater Quality

3.4.1. Methods

A matched-pairs statistical comparison has been applied to compare the means of water quality of the sample wells for 1970 and 1988. Th1s method 1s used to test the hypothesis that there is difference between the two means. Here, the two sample means may identify the water quality change for that time period. However, even a very large mean difference occurring in one comparison may not reflect real 
water quality change. It is necessary to determine whether the sample differences provide a basis for inferring actual water quality differences between the two time periods.

The concept of statistical significance helps to decide how much the sample means must differ in order for the null hypothesis to be rejected. The statistical test will show how likely a particular mean difference would be to occur by chance.

The two sets of values considered here are not independent of one another. The data are from the same wells at different times. The matched-pairs one tail t-test can take this fact into account. This method compares the difference of water quality from each well for the year of 1970 and 1988, which may greatly increase the sensitivity of the statistical tests.

3.4.2. Results and Discussion

Figure 3.1 shows water quality change of the sample wells from 1970 to 1988 . The results indicate that the concentration of nitrate in three wells decreased from 1970 to 1988 and one well showed no change. In other words, using nitrate as an indicator, groundwater quality degraded from 1970 to 1988 in seventeen wells out of the twenty-one sample wells. The concentration of chloride and sodium 


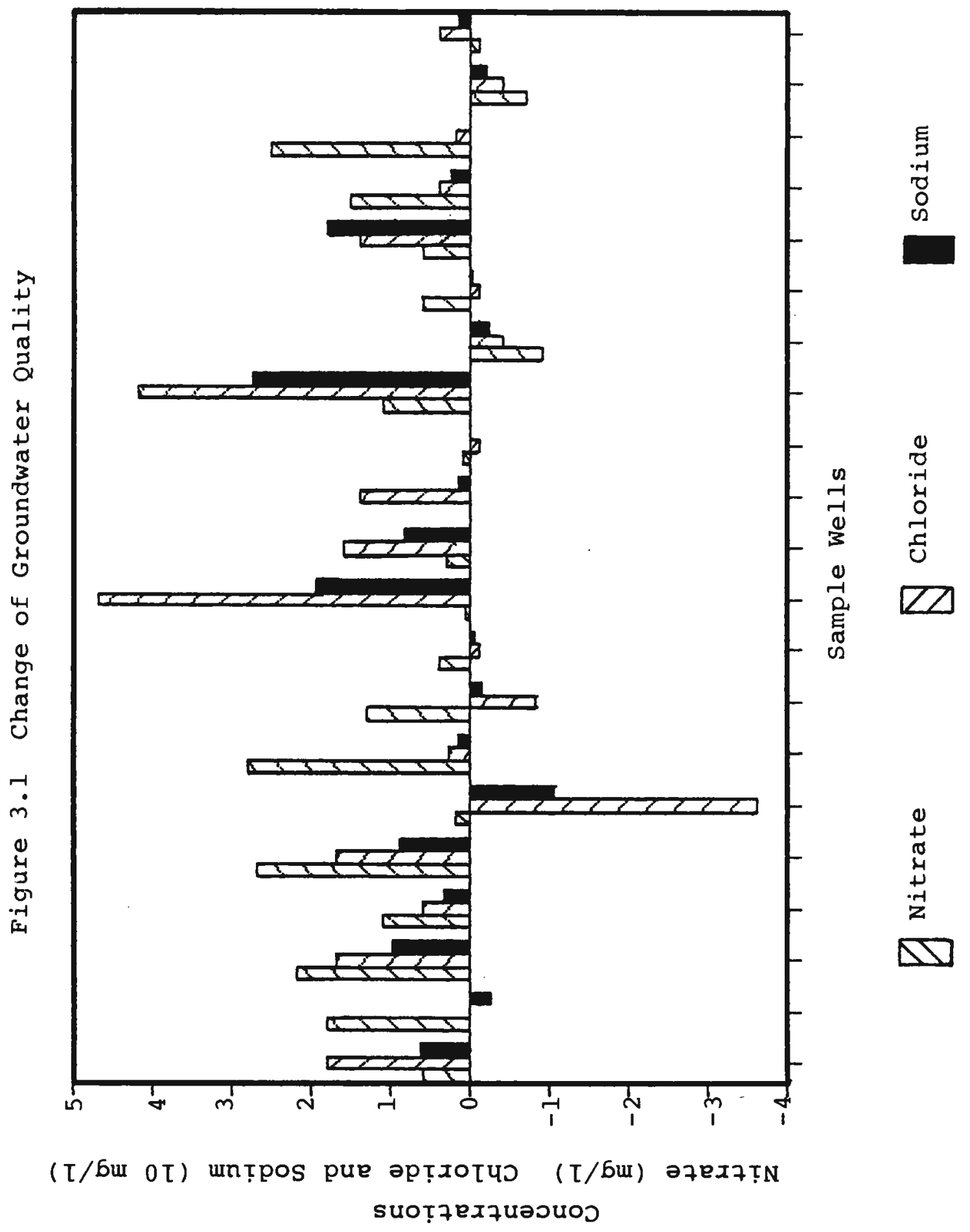


have similar patterns of change. Twelve wells show increases in chloride levels and sodium concentration in twelve wells increased from 1970 to 1988 .

The concentration changes observed of the three indicators further support the speculation that nitrate may come from different sources than chloride and sodium and that chloride and sodium may come from similar sources. Among the seventeen wells whose nitrate concentration increased, six wells experienced decrease or no change of the chloride concentration and sodium concentration. Two wells whose chloride and sodium concentrations increased did not show Increased nitrate concentrations. However, for all those wells whose chloride concentration in 1970 was greater than that of 1988 , sodium concentration had decreased during the same period.

The t-test results (Table 3.3) show that the mean of nitrate concentration for 1988 was $1.68 \mathrm{mg} / 1$ and for 1970 was $0.81 \mathrm{mg} / 1$. The difference between the two means is significant at 0.001 probability level. The mean of 1988 chloride concentration was $7.09 \mathrm{mg} / \mathrm{l}$ higher than the 1970 chloride mean concentration, which is different at 0.037 probability level. The mean of 1988 sodium concentration (15.79 $\mathrm{mg} / 1)$ was different from the mean of 1970 sodium concentration $(11.50 \mathrm{mg} / 1)$ at 0.017 probability level. 
Table 3.3 Paired t-Test Results of Groundwater Quality

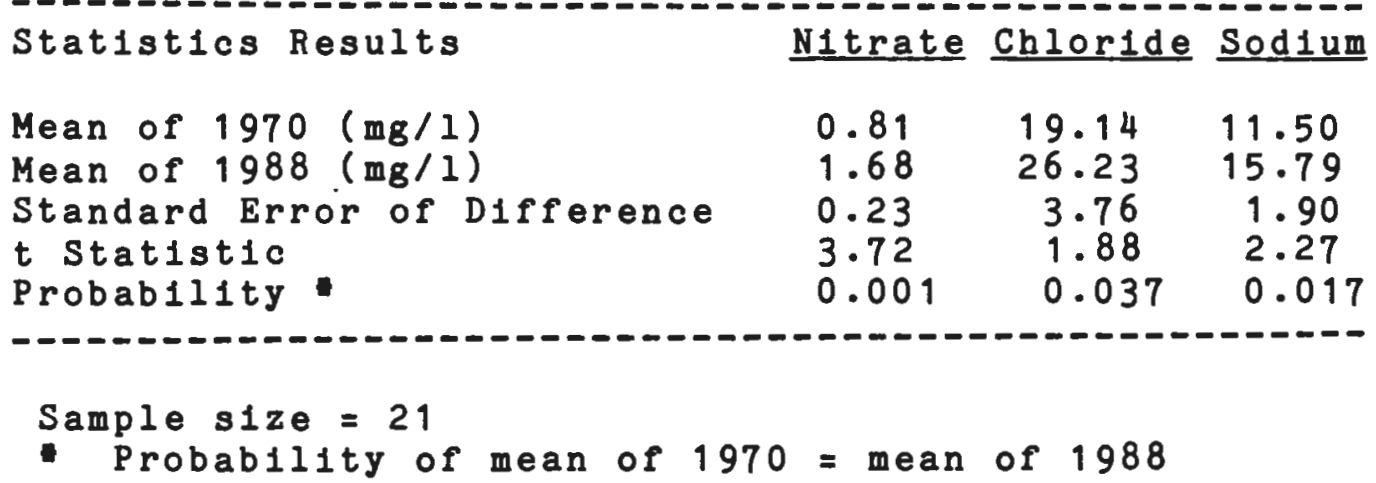

The analysis demonstrates that at the above probability level, it may be stated that for the same well, the nitrate, chloride, and sodium concentrations in 1988 were greater than that in 1970.

The water quality data indicate that nitrate and chloride concentrations in 1988 were still much lower than the RIDEM standards for drinking water. But, the 1988 mean sodium concentration was $15.8 \mathrm{mg} / 1$ and close to the recommended maximum concentration. Socium concentrations in some wells, were already higher than the recommended level.

All of the three indicators show trends of degradation of groundwater quality. The concentrations in 1988 were significantly greater than the concentrations in 1970. This is a strong indication that groundwater quality is 
subject to change and a large number of the study wells show degradation in water quality. Appropriate protection approach must be instituted to guard this important resource.

The analysis also reveals that sources of nitrate in groundwater may be different from the sources of chloride and sodium in groundwater. Chloride and sodium are likely from simllar sources. This will be further discussed in Chapter four. 


\section{CHAPTBR 4 LAHD USB SORHOUHDIHG TBB SAMPLB UBLLS}

After examining quality of selected constituents in public drinking water wells and finding that water quality had degraded from 1970 to 1988 , the next step is to find at what extent human activities affect water quality change. Following is a study of land use as a factor affecting groundwater quality degradation.

\subsection{Definition of Related Terms}

-- Drawdown. When pumping is started, the water level in the vicinity of a pumped well is lowered. The amount of the drop in the water level is called drawdown (Johnson 1982).

-- Cone of depression. The hydraulic gradient Increases as flow converges toward a pumping well. As a result, the lowered water surface develops a continualiy steeper slope toward the well. The form of this surface resembles a cone-shaped depression known as the cone of depression (Johnson 1982).

-- Radius of influence. It is the horizontal distance from the center of a well to the limit of the cone of depression. 
-- Water table. It is defined as the surface on which the fluid pressure in the pores of a porous medium is atmospheric (Ereeze 1979).

-.- Area of influence. The area of influence of a pumping well is the land area that directly overlies and has the same horizontal extent as the part of the water table or other potentiometric surface that is perceptibly lowered by the withdrawal of water (Morrissey 1987).

-- Contributing area. Contributing area of a pumping well is the land area that has the same horizontal extent as that part of an aquifer, or adjacent areas, from which groundwater flow is diverted to the pumping well.

\subsection{Concept of Contributing Area of a Pumping Well}

Contributing area can be shown as in figure 4.1. The figure shows a hypothetical water table before and after a well started pumping. As a result of pumping, the water table surrounding the pumping well is drawn down and groundwater flow changes direction within the area of influence. Some water is drawn into the pumping well that would otherwise pass by the well. This happens only in part of the influence area. On the other hand, some areas 
F1gure 4.1 Diagram of a Pumped Well Showing (A)

Cross-sectional View of the Zone of Division and

(B) Plan View of the Contributing Area
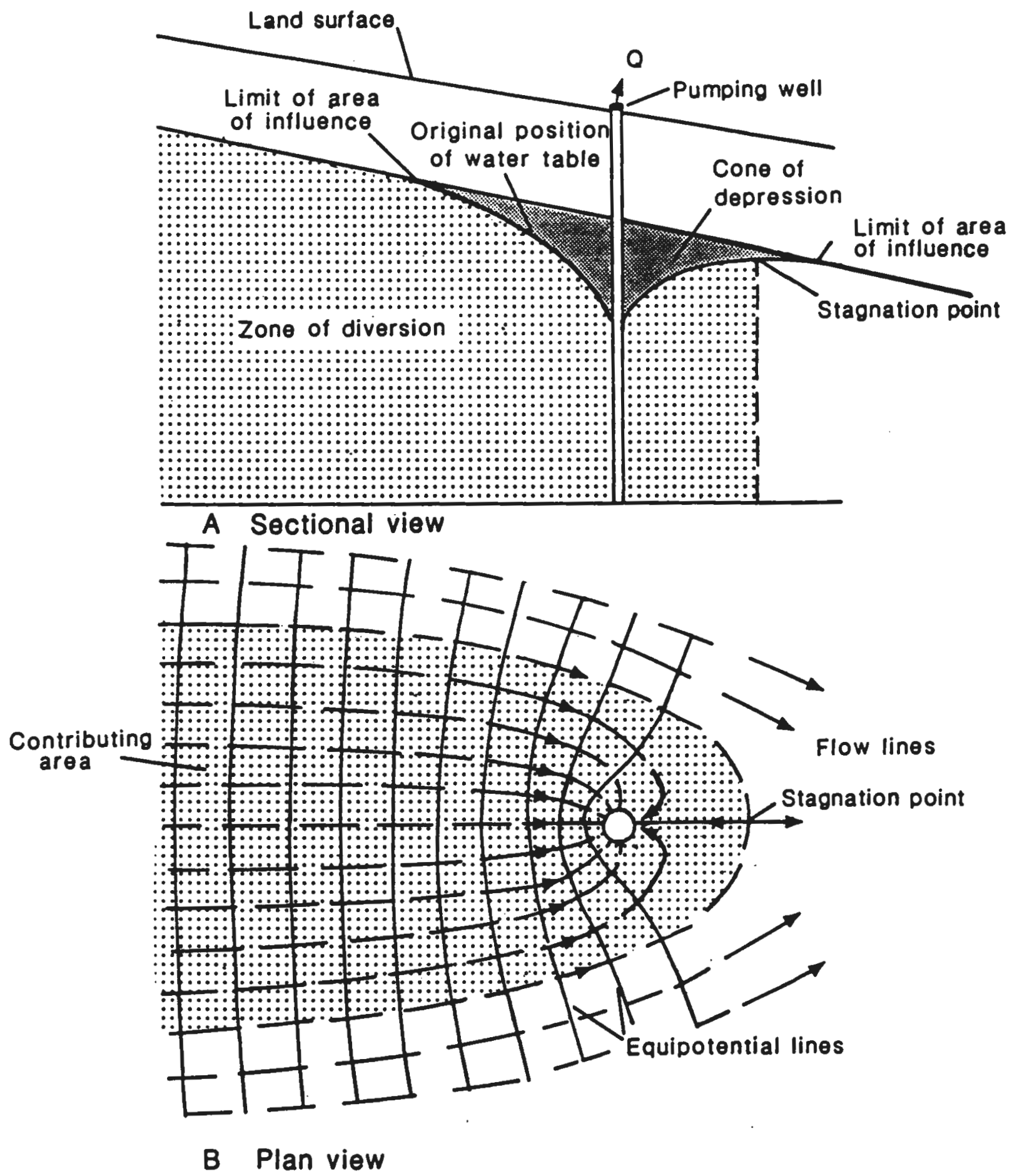

Source: Morr1ssey 1987. 
are not influenced by the pumping well, but water in this area will also naturaliy flow to the well. The groundwater contributing area will be distorted to extend to a greater distance than the influence area on the upgradient side, and to a lesser distance than the influence radius on the downgradient side.

The Influence area and the contributing area are two different concepts and the latter is more important to groundwater protection. Any pollutants in the contributing area will eventually reach the well and adversely affect the quality of water obtained from the well.

4.3. Identification of Contributing Area of a Pumping Well

\subsubsection{Factors afrecting contributing area}

The shape and size of the contributing area of a pumping well is determined by geohydrologic factors and well factors as shown in Table 4.1. These factors affect the discharge from and recharge to a pumping well to some degree depending upon specific conditions at the site.

The factors are divided into two groups. The first group includes geohydrologic factors which determine the characteristics of the area where a pumping well is 
Table 4.1 Factors Affecting the Contributing Area

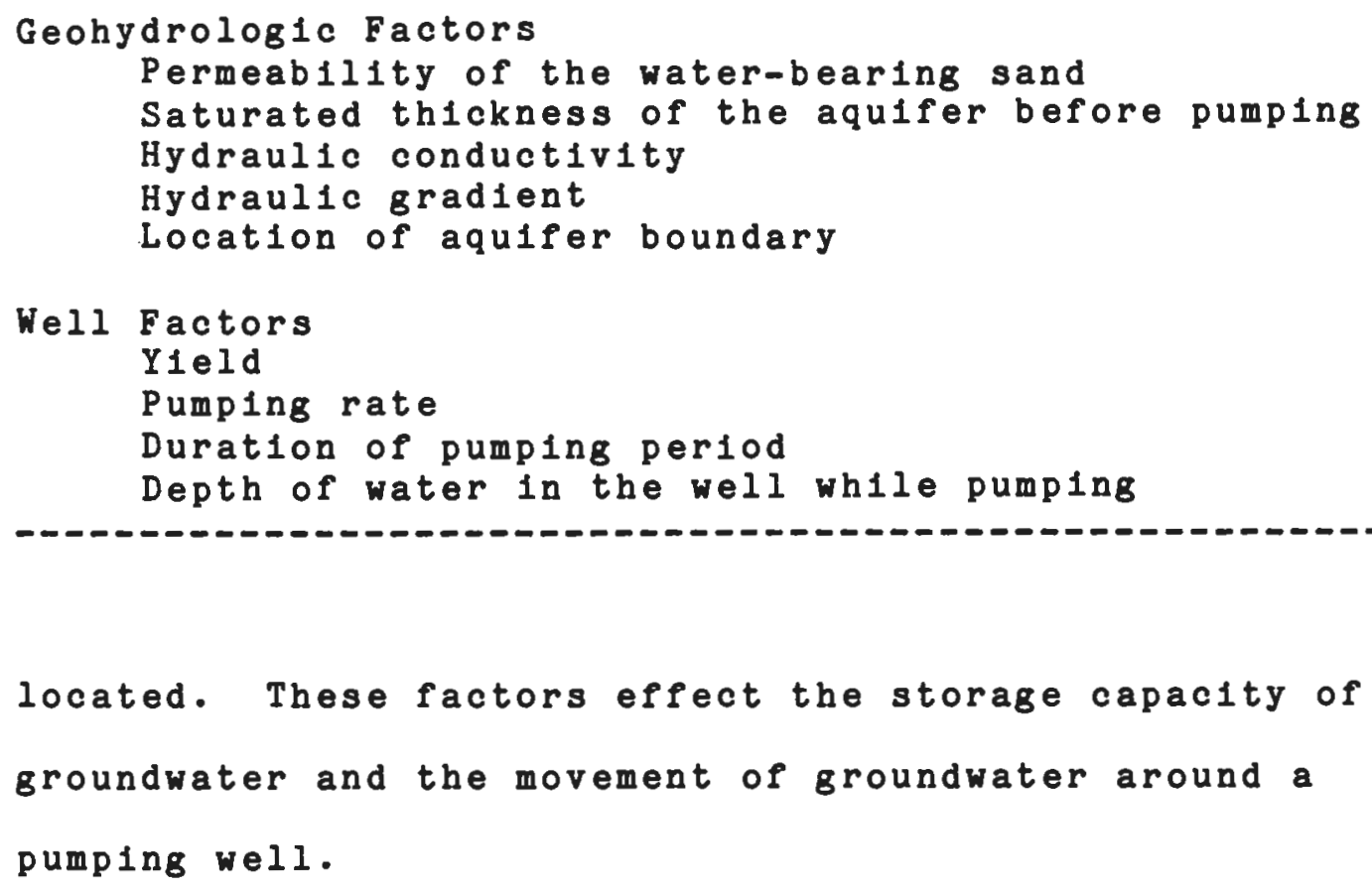

located. These factors effect the storage capacity of groundwater and the movement of groundwater around a pumping well.

Factors in the second group reflect the operation of a pumping well. These factors determine the amount and approach of drawing water. The two groups of factors together can determine water input and output from a pumping well site and therefore determine the shape and size of the contributing area of a pumping well.

When a group of wells are clustered together, wells may interfer with each other because of the increased drawdown. The contributing area of each well expands to intercept a larger area than a similar isolated well would require. 


\subsubsection{Hethods of delineating contributing area}

The concept of contributing area is fairly straight

forward. However, the delineation of the contributing area 1s more complex. It is difficult to measure the above factors accurately or directly.

Several methods are avallable for estimating the contributing area of a pumping well. The most commonly used methods are the fixed radius method, analytical model method, and numerical model method.

4.3.2.1. F1xed Rad1us.

This is the simplest method. A fixed radius is assigned to a pumping well. This method assumes the conditions surrounding a pumping well are evenly distributed. It simplifies the complexity of the situation into a single factor - the location of the well. The length of radius is mainly subjective determination based on previous study. On the one hand, it can only provide rough estimation of the contributing area. On the other hand, the method is easy, quick to apply and has low operating cost. Therefore, it is an appropriate method when the study is a preliminary analysis that could be followed with more complex modeling. 
4.3.2.2. Analytical Model.

This model is commonly used to evaluate aquifer characteristics from pumping test results. If aquifer characteristics are known or can be estimated, the analytical model can be used to delineate the contributing area of a pumping well. The analytical model has several assumptions, some of which are:

* the aquifer properties are homogeneous and isotropic;

* drawdowns caused by a well are unaffected by aquifer boundaries;

- the regional drawdowns that w1ll be caused by a pumping well are less than 10 percent of the total saturated thickness of an unconfined aquifer.

One sample equation of an analytical model is listed here, wh1ch was suggested by Todd (F1gure 4.2).

$$
\begin{aligned}
& -\bar{Y}=\tan \left(-\frac{2 T K B 1}{Q}---Y\right) \\
& X_{L}=-\frac{Q}{2 \mathrm{TKB}_{1}} \quad Y_{L}= \pm \frac{Q}{2 \mathrm{~Kb}_{1}}
\end{aligned}
$$


Where

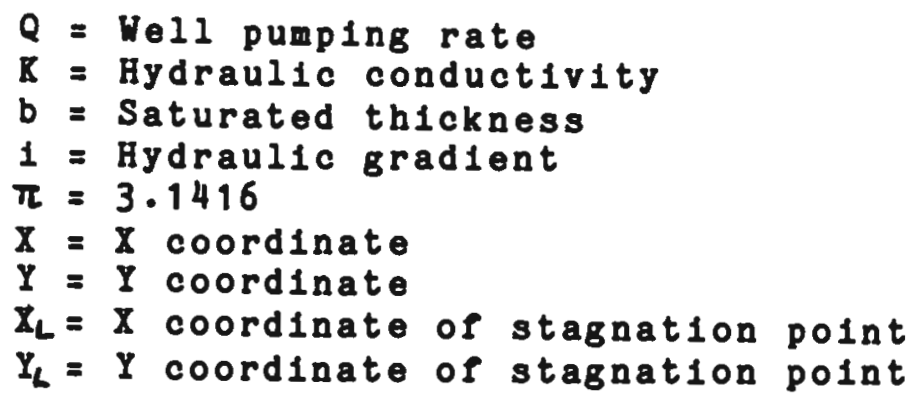

Figure 4.2 Flow to a Well Penetrating a Confined Aquifer Having a Sloping Plane Plezometric Surface.

(a) Vertical Section. (b) Plan View.
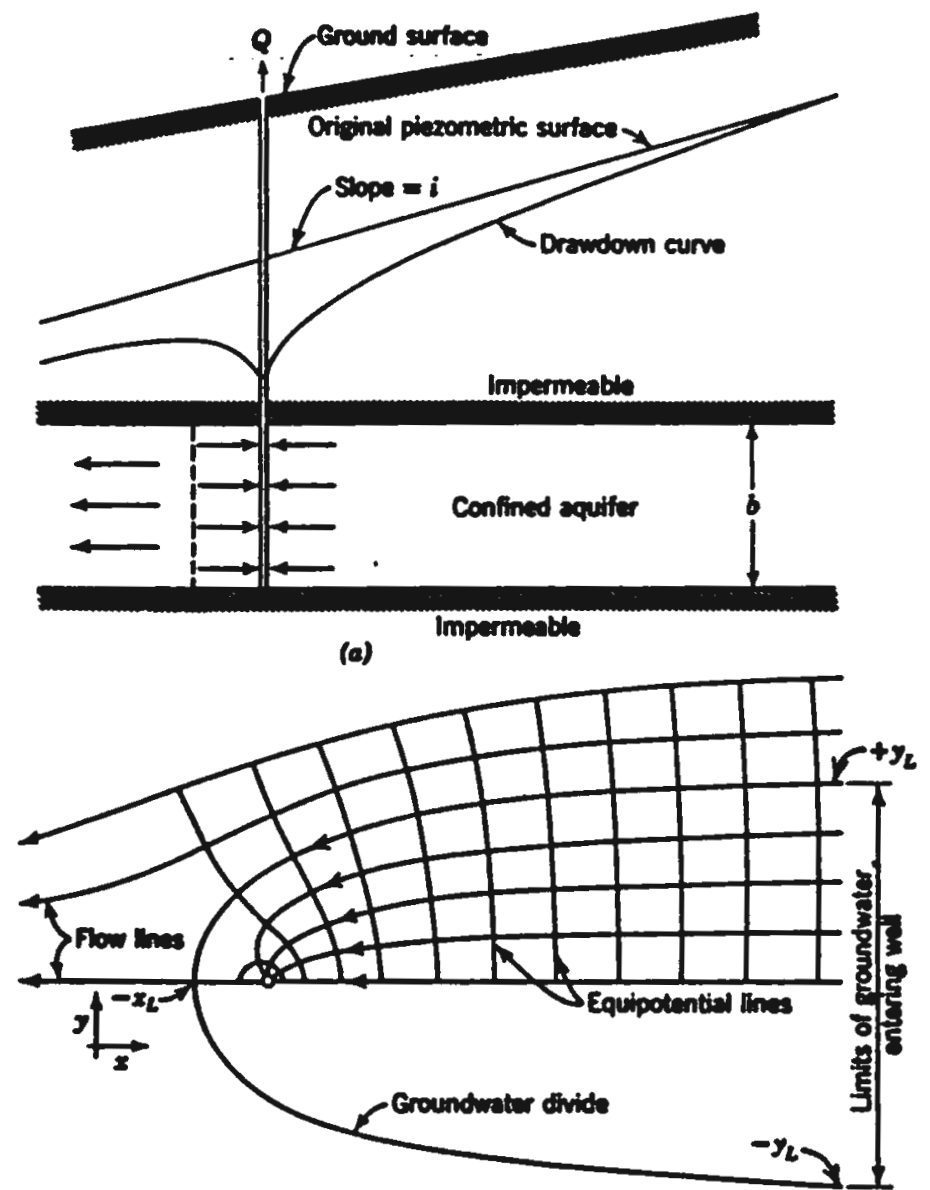

(b)

Source: Todd 1980. 
Because typical glacial-drift, river-valley aquifers are almost never homogeneous and pumping wells in these aquifers are usually affected by the presence of complicated boundaries such as surface water bodies and semipermeable valley walls, analytical models may result in considerable errors. There is no analytical model that can be used in every situation to estimate contributing areas for wells in glacial-drift aquifers. The suitability of an analytical approach must be considered on a site-by-site basis (Morrissey 1987).

4.3.2.3 Numerical Model.

A numerical model has the capability to solve a very wide range of complicated field problems and can simulate all of the previously listed factors that can affect the contributing area for a well. A two-dimensional numerical model can be used to simulate horizontal flow of groundwater in heterogeneous, anisitropic aquifers with either confined or unconfined conditions. It can also simulate irregular, mixed boundary conditions and complicated combinations of aquifer recharge and discharge. A three-dimensional numerical model can take into account vertical variations in geometry, hydraulic properties and recharge and discharge within an aquifer. 
Compared with the other two methods, the numerical model

takes longer time and has a higher requirements in

personnel, money, hardware, software, and data

availability. It is estimated that if all requirements are met, a two-dimensional numerical-model analysis may require anywhere from a few days to a few months of time (Morrissey 1987 ).

\subsubsection{Rationale for Selecting a Method}

This project is a preliminary analysis of the relationship of groundwater quality and land use for planning purposes. Based on the following considerations, the fixed radius method 1s applied. In addition, the geologic nature of the glacial drift is considered. Therefore, outwash deposits are separated from t111 deposits within the 1,000 foot radius study area.

1. Th1s research is not a detalled groundwater hydraulic study. Therefore the research does not attempt to determine exactly the contributing area. It rather applies a method which is relatively easy to conduct and provides accurate enough information for planning and management. The fixed radius method is an adequate method for this requirement. 
2. The analytical models and the numerical models need extensive data about the aquifer characteristics. Most of the data are not available or not accurate enough for applying the models without further testing. Such work was not possible within the constraints of the present study.

3. The Rhode Island Department of Environmental

Management has delineated recharge areas for the groundwater reservoirs as a circle with a 1,000 foot radius around each community water supply well. In this study, a 1,000 foot radius is applied, which may keep the study comparable with the work done by the state agency.

4. Outwash deposits have different geohydrologic characteristics than till deposits. Outwash consists of the sediment deposited by meltwater from receding glaciers. Interbedded layers of sand, gravel, silt, and clay comprise the sediment. In Rhode Island, outwash deposits typically yield large quantities of water to wells. Till deposits are usually very dense and relatively Impermeable, they do not yield large quantities of water to wells. 
4.4. Land Use Type within Study Areas

4.4.1. Data Collection

The aerial photographs covering the whole state are available at a five year increments for the past 20 years. Land use data for the 21 sample wells were collected from mylar prints of air photos of 1970 and 1988 at the Division of Planning, Rhode Island Department of Administration. This study divided land use into four categories: residential, commercial/industrial, agricultural, and undeveloped land. The boundaries of each land use type were interpreted from the air photos and digitized into ARC/INEO (Environmental Systems Research Institute, Redlands, CA) at the University of Rhode Island. The statistical function within ARC/INFO was used to calculate the total area for each type of land use within the 1,000 foot radius circle and on stratified drift deposits. Road system is another factor to be considered. According to the USGS topographic quadrangle map, roads were differentiated as paved and unpaved. Paved roads were further divided into heavy-medium duty roads and 1 ight duty roads. This was done because deicing salt is only used on paved roads and heavy-medium duty roads. For example, state highways would use more salt than light duty roads which are mainly local roads. 
The Environmental Data Center of the University of Rhode Island has stored road system data in ARC/INFO based on 1975 USGS Topographic Quadrangle Maps. This study applied the system and determined road data for 1970 and 1988 by dropping or adding roads from the existing data in accordance with the information from the air photos.

The Environmental Data Center at the University of Rhode Island has developed glacial deposit map data in its ARC/INFO system. The data are based on the Groundwater Map published by Rhode Island Water Resources Coordinating Board. In this study, only the area in glacial outwash deposits was identified as a subarea of the total contributing area. The purpose is to find the impact of different deposits.

4.4.2. Land Jae Distribution

Table 4.2 shows the land use types within the 1,000 foot radius areas of the twenty-one sample wells. Table 4.3 is the same land use type for the area with outwash deposits only.

Surface water bodies, which are ponds, lakes, and rivers, are found within the 1,000 foot radius areas of more than half of the sample wells. This implies the close relation of surface water and groundwater. Water can easily move 
Table 4.2. Land Use Types in Study Area (Whole Area) *

\begin{tabular}{|c|c|c|c|c|c|c|c|c|c|c|c|c|c|c|c|c|c|c|}
\hline \multirow[b]{2}{*}{ Well | } & \multirow[b]{2}{*}{$\begin{array}{l}\text { Water } \\
\text { ha. }\end{array}$} & \multirow[b]{2}{*}{8} & \multicolumn{8}{|c|}{1970} & \multicolumn{8}{|c|}{1988} \\
\hline & & & $\begin{array}{c}\text { Ondev } \\
\text { ha }\end{array}$ & eloped & $\begin{array}{c}\text { Agricu } \\
\text { ha }\end{array}$ & $\underset{8}{1 \text { tural }}$ & $\begin{array}{c}\text { Resid } \\
\text { ha }\end{array}$ & $\underset{8}{\text { ential }}$ & $\mathrm{ha}_{\mathrm{ha}}^{\mathrm{Com}}$ & \& Indu & $\begin{array}{c}\text { Undeve } \\
\text { ha }\end{array}$ & $\underset{8}{\text { eloped }}$ & $\begin{array}{c}\text { Agricul } \\
\text { ha }\end{array}$ & $\underset{8}{1 \text { tural }}$ & $\begin{array}{c}\text { Resid } \\
\text { ha }\end{array}$ & $\underset{8}{\text { lential }}$ & $\underset{\mathrm{ha}}{\mathrm{Comm}}$ & Indu \\
\hline $\begin{array}{r}3 \\
20 \\
89 \\
93 \\
95 \\
96 \\
98 \\
99 \\
101 \\
102 \\
104 \\
106 \\
108 \\
109 \\
120 \\
121 \\
142 \\
153 \\
157 \\
158 \\
166\end{array}$ & $\begin{array}{r}0.8 \\
10.6 \\
2.8 \\
0.6 \\
0.0 \\
2.0 \\
0.0 \\
0.0 \\
0.0 \\
0.0 \\
1.5 \\
7.6 \\
5.7 \\
3.3 \\
3.3 \\
0.0 \\
0.0 \\
4.1 \\
0.3 \\
0.0 \\
0.0\end{array}$ & $\begin{array}{r}2.8 \\
36.3 \\
9.6 \\
2.1 \\
0.0 \\
7.0 \\
0.0 \\
0.0 \\
0.0 \\
0.0 \\
5.3 \\
26.1 \\
19.5 \\
11.2 \\
11.3 \\
0.0 \\
0.0 \\
14.1 \\
0.9 \\
0.0 \\
0.0\end{array}$ & $\begin{array}{l}17.0 \\
12.7 \\
24.9 \\
23.4 \\
22.2 \\
19.6 \\
27.6 \\
22.8 \\
13.0 \\
28.1 \\
17.3 \\
18.4 \\
23.4 \\
25.6 \\
14.3 \\
21.1 \\
26.2 \\
10.7 \\
22.2 \\
19.0 \\
28.6\end{array}$ & $\begin{array}{l}58.3 \\
43.7 \\
85.5 \\
80.6 \\
76.4 \\
67.4 \\
94.9 \\
78.4 \\
44.8 \\
96.7 \\
59.6 \\
63.4 \\
80.5 \\
88.1 \\
49.0 \\
72.6 \\
90.1 \\
36.9 \\
76.5 \\
65.4 \\
98.4\end{array}$ & $\begin{array}{r}4.5 \\
0.0 \\
0.0 \\
0.0 \\
0.0 \\
1.0 \\
0.0 \\
2.7 \\
2.0 \\
0.2 \\
2.7 \\
0.0 \\
0.0 \\
0.0 \\
0.5 \\
2.8 \\
0.0 \\
14.2 \\
6.0 \\
9.5 \\
0.0\end{array}$ & $\begin{array}{r}15.5 \\
0.0 \\
0.0 \\
0.0 \\
0.0 \\
3.5 \\
0.0 \\
9.3 \\
6.8 \\
0.8 \\
9.2 \\
0.0 \\
0.0 \\
0.0 \\
1.8 \\
9.7 \\
0.0 \\
49.0 \\
20.7 \\
32.7 \\
0.0\end{array}$ & $\begin{array}{l}4.8 \\
5.8 \\
1.4 \\
1.4 \\
0.1 \\
3.1 \\
0.0 \\
1.9 \\
0.0 \\
0.0 \\
5.6 \\
0.5 \\
0.0 \\
0.2 \\
9.5 \\
0.4 \\
2.9 \\
0.0 \\
0.6 \\
0.6 \\
0.3\end{array}$ & $\begin{array}{r}16.5 \\
20.0 \\
4.9 \\
4.9 \\
0.5 \\
10.5 \\
0.0 \\
6.6 \\
0.0 \\
0.0 \\
19.3 \\
1.9 \\
0.0 \\
0.7 \\
32.7 \\
1.3 \\
9.9 \\
0.0 \\
1.9 \\
2.0 \\
1.1\end{array}$ & $\begin{array}{r}2.0 \\
0.0 \\
0.0 \\
3.6 \\
6.7 \\
3.4 \\
1.5 \\
1.7 \\
14.1 \\
0.7 \\
1.9 \\
2.5 \\
0.0 \\
0.0 \\
1.5 \\
4.8 \\
0.0 \\
0.0 \\
0.0 \\
0.0 \\
0.1\end{array}$ & $\begin{array}{r}6.9 \\
0.0 \\
0.0 \\
12.4 \\
23.1 \\
11.6 \\
5.1 \\
5.7 \\
48.4 \\
2.5 \\
6.6 \\
8.7 \\
0.0 \\
0.0 \\
5.2 \\
16.4 \\
0.0 \\
0.0 \\
0.0 \\
0.0 \\
0.5\end{array}$ & $\begin{array}{l}17.0 \\
12.6 \\
24.8 \\
20.8 \\
19.4 \\
13.3 \\
27.3 \\
22.8 \\
13.0 \\
28.1 \\
15.6 \\
18.4 \\
23.2 \\
25.6 \\
12.0 \\
20.5 \\
24.5 \\
10.5 \\
22.2 \\
19.0 \\
28.6\end{array}$ & $\begin{array}{l}58.3 \\
43.3 \\
85.3 \\
71.5 \\
66.6 \\
45.7 \\
94.0 \\
78.4 \\
44.8 \\
96.7 \\
53.6 \\
63.4 \\
79.8 \\
88.1 \\
41.4 \\
70.4 \\
84.2 \\
36.1 \\
76.5 \\
65.4 \\
98.4\end{array}$ & $\begin{array}{r}4.5 \\
0.0 \\
0.0 \\
0.0 \\
0.0 \\
0.0 \\
0.0 \\
1.7 \\
2.0 \\
0.2 \\
0.9 \\
0.0 \\
0.0 \\
0.0 \\
2.2 \\
2.9 \\
0.0 \\
14.5 \\
6.0 \\
9.5 \\
0.0\end{array}$ & $\begin{array}{r}15.5 \\
0.0 \\
0.0 \\
0.0 \\
0.0 \\
0.0 \\
0.0 \\
5.7 \\
6.8 \\
0.8 \\
3.1 \\
0.0 \\
0.0 \\
0.0 \\
7.7 \\
9.9 \\
0.0 \\
49.7 \\
20.7 \\
32.7 \\
0.0\end{array}$ & $\begin{array}{l}4.8 \\
5.9 \\
1.5 \\
3.9 \\
0.7 \\
9.0 \\
0.0 \\
3.0 \\
0.0 \\
0.0 \\
5.6 \\
0.5 \\
0.2 \\
0.2 \\
9.5 \\
0.4 \\
3.5 \\
0.0 \\
0.6 \\
0.6 \\
0.3\end{array}$ & $\begin{array}{r}16.5 \\
20.4 \\
5.0 \\
13.3 \\
2.5 \\
30.9 \\
0.0 \\
10.2 \\
0.0 \\
0.0 \\
19.3 \\
1.9 \\
0.7 \\
0.7 \\
32.7 \\
1.3 \\
12.2 \\
0.0 \\
1.9 \\
2.0 \\
1.1\end{array}$ & $\begin{array}{r}2.0 \\
0.0 \\
0.0 \\
3.8 \\
9.0 \\
4.8 \\
1.7 \\
1.7 \\
14.1 \\
0.7 \\
5.5 \\
2.5 \\
0.0 \\
0.0 \\
2.0 \\
5.4 \\
1.1 \\
0.0 \\
0.0 \\
0.0 \\
0.1\end{array}$ & $\begin{array}{r}6.9 \\
0.0 \\
0.1 \\
13.1 \\
30.8 \\
16.4 \\
6.0 \\
5.7 \\
48.4 \\
2.5 \\
18.8 \\
8.7 \\
0.0 \\
0.0 \\
6.9 \\
18.4 \\
3.6 \\
0.0 \\
0.0 \\
0.0 \\
0.5\end{array}$ \\
\hline Average & 2.0 & 7.0 & 20.9 & 71.8 & 2.2 & 7.6 & 1.9 & 6.4 & 2.1 & 7.3 & 20.0 & 68.7 & 2.1 & 7.3 & 2.4 & 8.2 & 2.6 & 8.9 \\
\hline
\end{tabular}

* Total area 29.1 hectares ha $=$ hectare

$8=$ percent of total area

Comm Indu = Commercial and Industrial 
Table 4.3. Land Use Types in Study Area (Outwash Only) *

$$
1970
$$

1988

Total Outwash Undeveloped Agricultural Residential Corm \& Indu Undeveloped Agricultural Residential Comm \& Indu

\begin{tabular}{|c|c|c|c|c|c|c|c|c|c|c|c|c|c|c|c|c|c|c|}
\hline 11 & ha & 8 & ha & 8 & $h=$ & 8 & ha & 8 & ha & 8 & ha & 8 & ha & 8 & ha & 8 & ha & 8 \\
\hline $\begin{array}{r}3 \\
20 \\
89 \\
93 \\
95 \\
96 \\
98 \\
99 \\
101 \\
102 \\
104 \\
106 \\
108 \\
109 \\
120 \\
121 \\
142 \\
153 \\
157 \\
158 \\
166\end{array}$ & $\begin{array}{r}29.1 \\
9.4 \\
21.5 \\
23.4 \\
25.7 \\
22.2 \\
29.1 \\
0.0 \\
25.0 \\
28.5 \\
29.1 \\
16.3\end{array}$ & $\begin{array}{r}21.8 \\
63.7 \\
62.2 \\
97.9 \\
100.0 \\
93.0 \\
100.0 \\
100.0 \\
100.0 \\
100.0 \\
32.5 \\
73.9 \\
80.5 \\
88.4 \\
76.2 \\
100.0 \\
0.0 \\
85.9 \\
98.1 \\
100.0 \\
56.0\end{array}$ & $\begin{array}{r}16.7 \\
23.4 \\
22.2 \\
19.6 \\
27.6 \\
22.8 \\
13.0 \\
28.1 \\
7.9 \\
18.4 \\
23.4 \\
25.5 \\
10.9 \\
21.1 \\
0.0 \\
10.7 \\
22.0 \\
19.0 \\
15.8\end{array}$ & $\begin{array}{r}37 . \\
72 . \\
0 . \\
36 . \\
75 \\
65 \\
54 .\end{array}$ & $\begin{array}{r}0.0 \\
0.0 \\
0.0 \\
0.0 \\
1.0 \\
0.0 \\
2.7 \\
2.0 \\
0.2 \\
0.0 \\
0.0 \\
0.0 \\
0.0 \\
0.5 \\
2.8 \\
0.0 \\
14.2 \\
6.0 \\
9.5 \\
0.0\end{array}$ & $\begin{array}{r}0.0 \\
0.0 \\
0.0 \\
0.0 \\
3.5 \\
0.0 \\
9.3 \\
6.8 \\
0.8 \\
0.0 \\
0.0 \\
0.0 \\
0.0 \\
1.8 \\
9.7 \\
0.0 \\
49.0 \\
20.6 \\
32.7 \\
0.0\end{array}$ & ?. & $\begin{array}{r}0.5 \\
20.0 \\
4.9 \\
4.9 \\
0.5 \\
10.5 \\
0.0 \\
6.6 \\
0.0 \\
0.0 \\
0.1 \\
1.9 \\
0.0 \\
0.7 \\
32.0 \\
1.3 \\
0.0 \\
0.0 \\
1.9 \\
2.0 \\
1.1\end{array}$ & $\begin{array}{l}1.5 \\
2.5 \\
0.0 \\
0.0 \\
1.5 \\
4.8 \\
0.0 \\
0.0 \\
0.0 \\
0.0 \\
0.1\end{array}$ & $\begin{array}{r}2.5 \\
5.1 \\
8.7 \\
0.0 \\
0.0 \\
5.1 \\
16.4 \\
0.0 \\
0.0 \\
0.0 \\
0.0 \\
0.5\end{array}$ & $\begin{array}{r}8 \\
20 \\
0 \\
10\end{array}$ & $\begin{array}{r}0 \\
36\end{array}$ & $\begin{array}{r}0.0 \\
2.2 \\
2.9 \\
0.0 \\
14.5 \\
6.0 \\
9.5 \\
0.0\end{array}$ & $\begin{array}{l}0 \\
0 \\
0 \\
0 \\
0 \\
7 \\
9 \\
0\end{array}$ & $\begin{array}{l}1 \\
9 \\
5 \\
8 \\
7 \\
0 \\
0 \\
0\end{array}$ & $\begin{array}{r}0.5 \\
20.4 \\
5.0 \\
13.1 \\
2.5 \\
30.9 \\
0.0 \\
10.2 \\
0.0 \\
0.0 \\
0.1 \\
1.9 \\
0.7 \\
0.7 \\
32.0 \\
1.3\end{array}$ & $\begin{array}{l}2.0 \\
5.4 \\
0.0 \\
0.0 \\
0.0 \\
0.0 \\
0.1\end{array}$ & $\begin{array}{r}1.6 \\
0.0 \\
0.1 \\
13.3 \\
30.8 \\
16.4 \\
6.0 \\
5.7 \\
48.4 \\
2.5 \\
8.4 \\
8.7 \\
0.0 \\
0.0 \\
6.8 \\
18.4 \\
0.0 \\
0.0 \\
0.0 \\
0.0 \\
0.5\end{array}$ \\
\hline verage & 22.6 & 77.6 & 17.5 & 0.0 & .9 & 0.4 & 20 & 4.2 & 2.0 & 7.0 & 10.1 & 51.3 & 1.9 & 0.4 & 1.7 & 5.9 & 2.3 & 8.0 \\
\hline
\end{tabular}

* Total area 29.1 hectares

ha $=$ hectare

8 = percent of total area

comm \& Indu = Commercial and Industrial 
between groundwater and surface water. This phenomenon has significant impact on groundwater protection. Pollutants may travel long distances through surface water and contaminate the groundwater in the well site.

Among the twenty-one sample wells, only one well does not have outwash deposit within its 1,000 foot radius area. The study areas of ten wells are completely in the outwash deposit areas.

Undeveloped land is a major land use type. In 1970, in average about seventy-two percent of the study area was undeveloped land. The figure for 1988 was sixty-nine percent. Well 166 had the highest percentage of undeveloped area - 98.4 percent. The lowest figure was well $153,36.13$ percent.

Agricultural land percentage shows a great range of difference. Ten well sites did not have any agricultural land and well 153 had the highest percent of farm land, forty-nine percent, in 1970

Residential land forms a similar pattern to farm land. The percentage varied from zero to 32.7 percent. In $1988, \mathrm{six}$ wells had less than one percent residential areas and five wells had more than fifteen percent residential areas. The 
commercial and industrial activities in the sample well sites also exhibit the variance among different sites, from zero to 48.4 percent.

The large variation in agricultural, commercial/industrial and residential land use implies that the sample wells cover areas in different development stages, from rural, suburban to urban. The results from these sample wells are expected to be highly representative of the state.

\subsubsection{Land Jae Change}

Data in table 4.2 and table 4.3 show that only five well sites had experienced residential land area increase greater than 1 percent of the study area, that $1 \mathrm{~s}$, more than 0.3 hectares. If residential land and commercial and industrial land are considered together, new development in eight well sites was greater than 1 percent of the study area. Nine well sites had no change at all and other four well sites had new development less than 1 percent of the total area.

A paired t-test is used again for the comparison of land use of 1970 and land use of 1988. Table 4.4 and Table 4.5 are the results for residential, commercial/industrial, agricultural, and undeveloped land for all the study areas and for the areas within outwash deposit only. The same trend can be seen for the whole 1,000 foot radius area and 
the outwash subarea. The results of the test indicate that the undeveloped area had decreased significantly.

Residential type and industrial/commercial type land use had increased significantly. Agricultural land had decreased slightly, but not at a statistically significant level. This result shows that most new development in these areas had converted undeveloped land into residential, commercial, or industrial land.

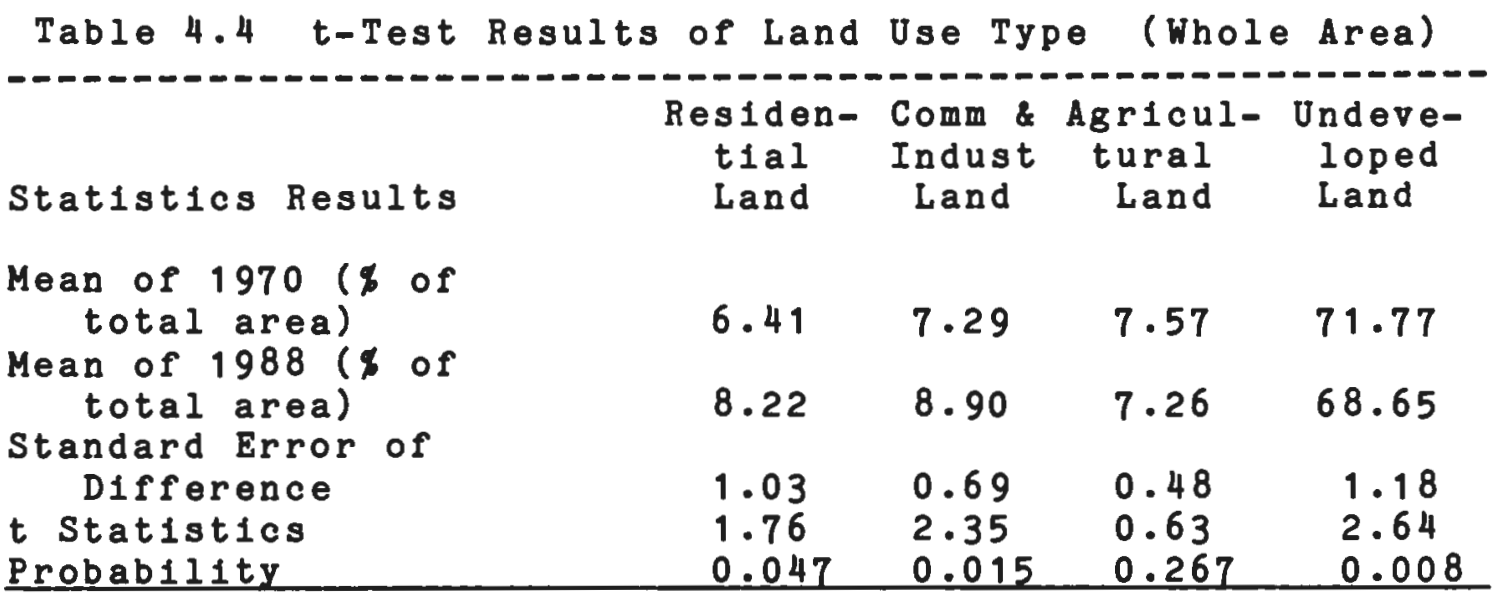
Sample size $=21$

Total area $=29.1$ hectares

Table 4.5 t-Test Results of Land Use Type (Outwash Only)

\begin{tabular}{|c|c|c|c|c|}
\hline Statistics Results & $\begin{array}{l}\text { Residen- } \\
\text { tial } \\
\text { Land }\end{array}$ & $\begin{array}{l}\text { Comm } \\
\text { Indust } \\
\text { Land }\end{array}$ & $\begin{array}{l}\text { Agricul- } \\
\text { tural } \\
\text { Land }\end{array}$ & $\begin{array}{l}\text { Undeve- } \\
\text { loped } \\
\text { Land }\end{array}$ \\
\hline $\begin{array}{l}\text { Mean of } 1970 \text { (\$ of } \\
\text { total area) } \\
\text { Mean of } 1988 \text { ( } \$ \text { of }\end{array}$ & 4.23 & 6.96 & 6.39 & 60.05 \\
\hline $\begin{array}{l}\text { total area) } \\
\text { Standard Error of } \\
\text { Difference } \\
\text { t Statistics } \\
\text { Probability }\end{array}$ & $\begin{array}{l}1.03 \\
1.64 \\
0.058\end{array}$ & $\begin{array}{l}0.44 \\
2.35 \\
0.015\end{array}$ & $\begin{array}{l}0.38 \\
0.034 \\
0.487\end{array}$ & $\begin{array}{l}1.17 \\
2.31 \\
0.016\end{array}$ \\
\hline
\end{tabular}

Sample size $=21$

Total area $=29.1$ hectares 


\section{CHAPTBR 5 GROUHDHATBR QUALITT AHD LAHD USB}

5.1. The Relationship of Groundwater Quality and Land Use

5.1.1. Sinple Linear Regression Analysis

A simple linear regression model is applied to analyze the water quality and land use data and the results are presented in Table 5.1. Previous studies have shown that nitrate in groundwater is likely from agricultural land, residential areas and some commercial and industrial activities. For chloride and sodium, in addition to the three sources, deicing salt on road systems is a major source.

Nitrate, chloride, and sodium were dependent variables. In the first part of regression analysis, the independent variables include the area of commercial/industrial, residential, agricultural land, the length of paved light duty roads, paved heavy-medium duty roads, and the length of total paved roads within the 1,000 foot radius study area.

In the second part of the regression analysis, the area of outwash deposits is considered as a control factor. Table 5.1 shows the regression coefficients of water quality Indicators and different land use above outwash deposits. 
Table 5.1 Simple Correlation Coefficients of Water Quality and Land Use

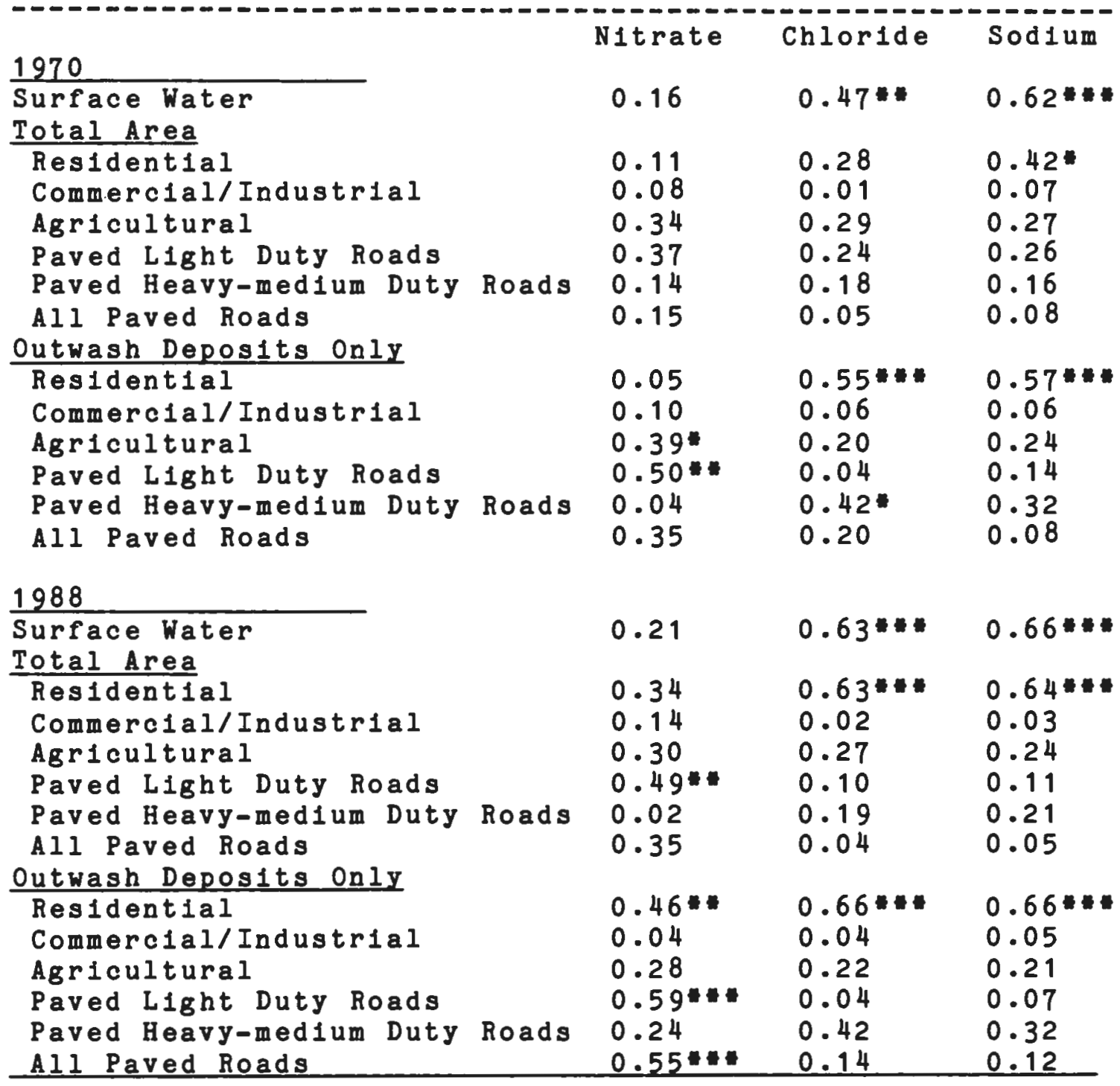

Water quality is mg/l. Land use is percent of total area.

The probability of correlation coefficients equal to zero is as follows:

$*$ Prob $|r|=0<0.01$

* Prob $|r|=0<0.05$

- Prob $|r|=0<0.1$ 
The regression coefficients of water quality and land use above outwash deposits have higher values than the coefficients with the land use figure for the whole area, which includes both outwash and till deposits. This could be an Indication that water quality may be more closely related to land use above the outwash deposits and pollutants in outwash deposits have greater impacts on groundwater quality than those in till deposits. Therefore, the following analysis will focus on the land use above outwash deposit only.

Area of surface water bodies is considered as an additional factor which may reflect the impact of activities outside of the 1,000 foot radius area.

The correlation coefficients are relatively low and vary from 0.01 to 0.66 . Several possible reasons may explain these low correlations. First, some factors other than land use, such as land fills or underground storage tanks may have an impact on the water quality. Second, the 1,000 foot radius circle may only cover part of the actual contributing area of a pumping well, the area within the contributing area but outside the circle may also provide pollutants to groundwater. This study did not count that part of the contribution. Third, most sample wells are located close to ponds, lakes, or streams. The watersheds of these surface water bodies are usually much larger than 
the contributing area of a pumping well. Thus, development in the watersheds may contribute pollutants to the surface water body and surface water recharge may affect the quality of groundwater.

The nitrate concentration of 1970 and the concentration of 1988 show the different pattern of correlation with land use. In 1970, the correlation coefficient between the nitrate concentration of the wells and agricultural land was 0.39 . The probability of no correlation was zero. The coefficient of nitrate concentration with farm land in 1988 was 0.28 . The probability of the coefficient equal to zero was twenty-two percent. This can be interpreted to reveal that in 1970 there was a positive relation between farm land area and nitrate concentration in wells but, this relation did not exist in the 1988 data.

The correlation coefficients of nitrate concentration and residential land use was 0.05 in 1970 and 0.46 in 1988. This infers that the nitrate concentration in 1970 was not related to residential land and that in 1988 , the correlation between these two variables was very obvious. 
It may be concluded that in 1970 farm land contributed nitrate to groundwater and in 1988 , residential land played a more important role in providing nitrate to groundwater than farm land did. This may be a consequence of new residential development.

The correlation analysis of both chloride and sodium concentration with land use show that the two indicators have a similar pattern. The coefficients with residential land were 0.55 for 1970 and 0.66 for 1988 . Paved heavy-medium duty roads had the next highest coefficients with value above 0.32 . The coefficients was not at a statistical significant level.

The coefficients of chloride or sodium with light duty roads and commercial/industrial land were very low. There was no any correlation among these variables.

The analysis also indicates a relatively strong correlation between chloride concentration and surface water, as well as between sodium concentrations and surface water. Surface water area as a factor reflects the impact of activities beyond the study area. Usually, a large water body has a large watershed and may bring in more pollutants Into the groundwater. 


\subsubsection{Multiple Regression Analjsis}

In addition to the simple linear correlation analysis, a multiple regression model was used to analyze the combined effects of the land use factors on the water quality of sample wells based on 1988 data. The dependent variables were the concentration of nitrate, the concentration of chloride, and the concentration of sodium. The independent varlables were chosen from every land use and road types by using a stepwise multiple regression analysis.

The criterion of selection was set up at 0.05 significant level. The results of the analysis show that in the model for nitrate, independent variables are agricultural land, residential land, paved light duty roads, and surface water. Chloride is only related to residential land and surface water. The model for sodium includes residential land, Industrial/commercial land, paved light duty road, and surface water.

A multiple regression model was applied for analyzing the relations of the dependent variables and selected independent variables. Figure 5.1 shows the causal model for nitrate. The model includes four independent variables. The overall $R$ squared for the four variables is 0.607 with an adjusted $R$ squared of 0.509 . This indicates 
Figure 5.1 Causal Variables of Nitrate Concentrations (Outwash Only 1988)

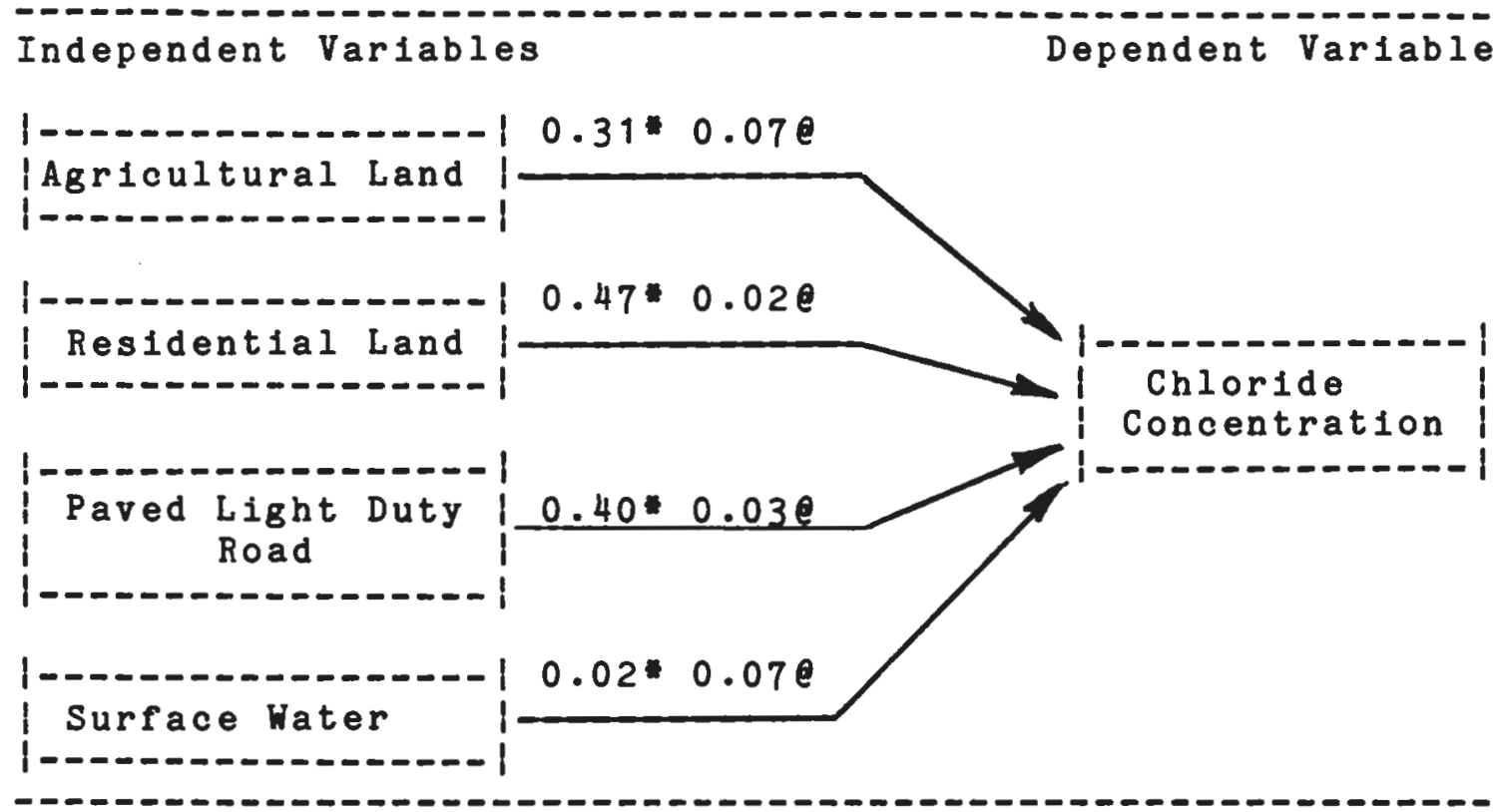

$R$ Squared $\quad=0.607$

Adjusted $R$ squared $=0.509$

- Standardized Regression Coefficient

e Probability of coefficient $=0$

that approximately 50.9 percent variation in nitrate concentration is explained by agricultural land, residential land, paved light duty roads, and surface water bodies.

In the chloride model as shown in Figure 5.2 , the overall $R$ squared for the three variables is 0.631 with an adjusted $R$ squared of 0.590 . The overall $R$ squared for the sodium model (Figure 5.3) is 0.832 with an adjusted $R$ squared of 0.789 . 
Figure 5.2 Causal Variables of Chloride Concentrations (Outwash only 1988)

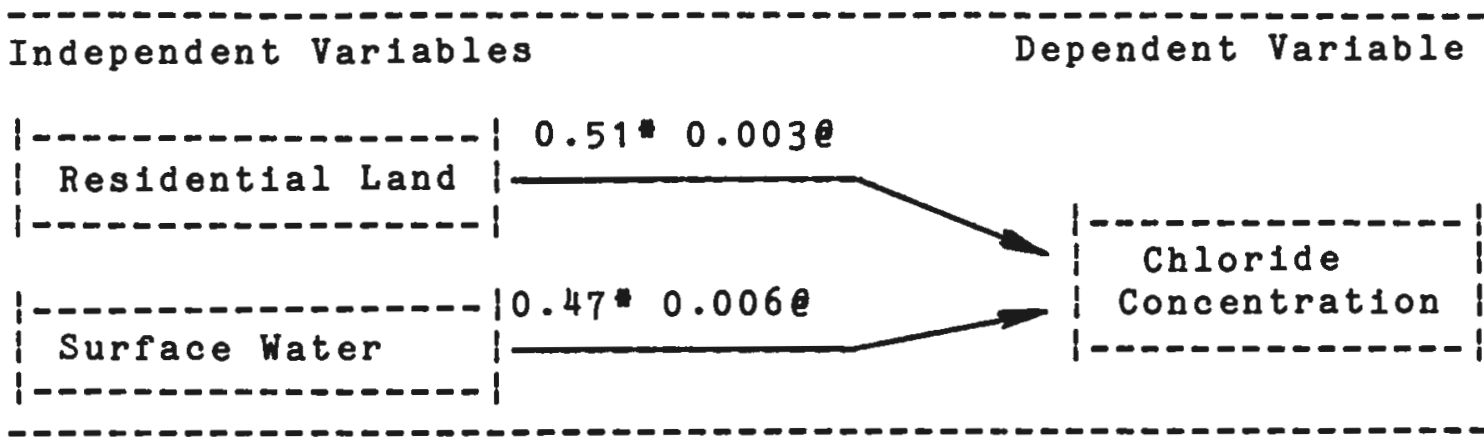

$R$ Squared $\quad=0.631$

Adjusted $R$ Squared $=0.590$

- Standardized Regression Coefficient

e Probability of coefficient $=0$

Figure 5.3 Causal Variables of Sodium Concentrations (Outwash only 1988)

Independent Variables Dependent Variable

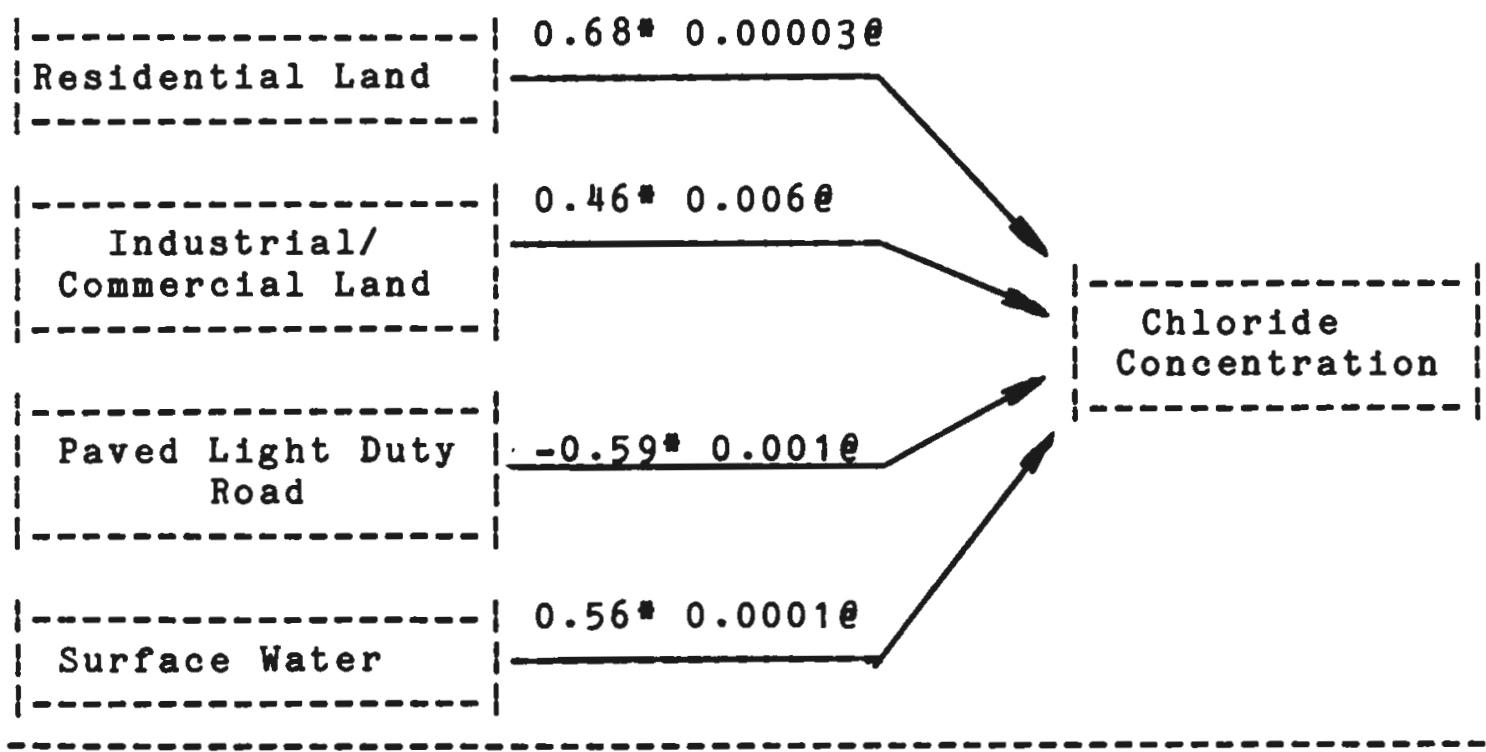

$R$ Squared $\quad=0.832$

Adjusted R Squared $=0.789$

- Standardized Regression Coefficient

e Probability of coefficient $=0$ 
This finding indicates that approximately 59.0 percent of the variation in chloride concentration and approximately 78.9 percent of the variation in sodium concentration are explained by these independent variables.

The standardized regression coefficient for the variables, except the paved light duty roads in sodium model, are all greater than zero. This implies that there are positive relationships between the dependent variable and Independent variables. That is, the concentration of nitrate, chloride or sodium in groundwater increases with the increase of area of Industrial/commercial land or residential land. It also implies that the wells close to large surface water bodies are more likely to be endangered by chloride and sodium than wells far from large surface water bodies.

Based on the above findings, it is concluded that residential land and surface water are two major factors in the levels of chloride and sodium concentrations in the wells and that nitrate concentrations in the wells are closely related to residential land and paved light duty roads. 
5.2. Relationship of Hater Quality Change and Land Use Change

Table 5.2 gives the results of the regression analysis of the change of water quality and the change of land use. From the analysis of Chapter four, agricultural land did not change significantly from 1970 to 1988. Therefore, the land use types discussed will be the undeveloped land, residential land, and commerclal/industrial land.

The results show that the change of nitrate concentration is related to the change of residential area at a 0.01 probability level $(r=0.55, n=21, p<0.01)$ and to the change of undeveloped land at 0.06 probability level $(r=0.43$, $n=21, p(0.06)$. There is no statistically significant correlation between the change of nitrate concentration and the change of commercial/industrial land $(r=0.13, n=21$, $p(0.59)$. The change of chloride concentration is not related to residential land $(r=0.17, n=21, p<0.46)$ and bears only a limited relation to industrial/commercial land $(r=0.26, n=21, p<0.26)$. Sodium concentration shows a similar pattern with low correlation coefficients with residential land $(r=0.16, n=21, p<0.49)$ and with 1ndustrial/commercial land $(r=0.24, n=21, p<0.30)$. 
Table 5.2 Correlation Analysis of Land Use Change and Water Quality Change (Outwash only)

Correlation With Nitrate

Land Use Type

N Correlation R-Squared Prob $|r|=0$

Undeveloped

21

0.4251

0.1807

0.055

Residential

210.5503

0.3028

0.010

Industrial+Commercial

21

0.1259

0.0159

0.587

Correlations with Chloride

Land Use Type

Undeveloped

$\mathrm{N}$

Residential

\section{1}

21

Correlation

$\begin{array}{cc}\text { R-Squared } & \text { Prob }|r|=0 \\ 0.1177 & 0.128 \\ 0.0287 & 0.463 \\ 0.0651 & 0.264\end{array}$

Industrial+Commercial

$21 \quad 0.2551$

0.0651

0.264

Correlations with Sodium

Land Use Type

Undeveloped

N Correlation R-Squared Prob $|r|=0$

Resident

21

0.3652

0.1586

0.1333

0.104

Industrial+Commercial

210.2362

0.0252

0.492

Industrialt Commeroial

0.0558

0.303

The highest correlation is between the three water quality

indicators and undeveloped land with a negative coefficient value. This implies that groundwater may be degraded after undeveloped land has been developed.

Simple correlation coefficients were calculated for the three independent variables. The results indicated that there was a high correlation between the change of undeveloped land and the change of residential land $(r=-0.88, n=21, p=0)$.

A high coefficient value was also found between the change of undeveloped land and the change of commercial/industrial land $(r=-0.74, n=21, p=0)$. A t-test showed that these relations were 100 percent significant. 
The correlation coefficient for residential land and Industrial/commercial land shows that the two variables are also correlated $(r=0.45, n=21, p<0.04)$.

Based on these results it is concluded that a multiple regression analysis is not appropriate because of the autocorrelation between the independent variables. 


\section{CHAPTBR 6 SUHHART}

Rhode Island has the distinction of being one of the nation's most densely populated states and over the past decades it has witnessed an unprecedented increase in the rate of development. The state has abundant groundwater resources. However, pollution is threatening the quality of the water resources. The state's stratified drift aquifers have the potential for supplying future and existing public water supply systems with large quantities of groundwater. Stratified drift deposits, or outwash deposits, are extremely vulnerable to contamination from a wide variety of pollution sources which include nonpoint and point sources. This is in part due to the generally rapid permeability.

Point pollution sources are relative easy to control. Most acts and regulations have primarily been addressed to point pollution sources. The Safe Drinking Water Act (SDWA) as amended in 1986 authorizes the setting, monitoring, and enforcement of drinking water standards and provides for the protection of underground sources of water through controls on land-based activities. The clean Hater Act (CWA) as amended in 1987 regulates the discharge of pollutants from industrial sources and from publicly-owned 
treatment works (POTWs). This Act has provided funding to states to set up groundwater management plans and to address nonpoint pollution.

Nonpoint pollution sources are very difficult to regulate. The most effective way is the Best Management Plan or nonpoint source management approach. The nonpoint source assessment process has proven valuable in determining the extent and magnitude of nonpoint sources of pollution. This research is an effort to assess the impacts of nonpoint sources of pollution on groundwater and to provide basic information for protecting groundwater.

This report explores the existing condition of water quality in some of Rhode Island's public drinking water wells and the relationship between land use and groundwater quality. The statistical analysis of the twenty-one sample well sites showed that there was a significant increase of residential, commercial, and industrial land within a designated groundwater contribution zone from 1970 to 1988. Although the data in 1988 indicated that the public drinking water quality was, overall, in good condition, the concentrations of nitrate, chloride, and sodium indicated that the groundwater had degraded significantly since 1970. 
The analysis of water quality and land use shows that residential land is providing nitrate, chloride, and sodium to groundwater. Paved light duty roads are also related to nitrate concentration in groundwater.

Areas within 1,000 feet radius around public drinking water supply wells are crucial to groundwater protection. Nonpoint pollution sources within a 1,000 foot radius circle around a pumping well provide pollutants to the well. However, they are not the only sources.

Attention should also be given to the area beyond the 1,000 foot limit. The discussion of contributing area will help to understand that the 1,000 foot radius circle may only be part of the contributing area. Pollutants from other nonpoint pollution sources in the contributing area will eventually arrive at the pumping well. The nonpoint source management plan needs to cover the entire contributing area.

The high correlation coefficients between chloride and sodium concentrations and surface water area indicate that pollutants may come from larger areas through surface flow. Because of the close relation between groundwater and surface water, it is important to make appropriate land use plans for the watershed of surface water for the purpose of protecting groundwater. 
It can be concluded from the research that urbanization has an 1mpact on groundwater quality. This is a preliminary study of the factors of groundwater pollution. Many different variables could be considered for explaining the degradation of groundwater quality. Further studies will need to Include more independent varlables such as point source pollution components. By Increasing the sample size, more valuable findings are expected. 


\section{REF BRBHCBS}

Bouwer, Herman. 1978. Groundwater Hydrology. New York: Mcgraw-Hill Book Company.

Concern, Inc.(a). 1988. Drinking Water.

Concern, Inc.(b). 1988. Groundwater.

Edwards, Allen L. 1973. Statistical Methods, 3rd Edition. New York: Holt, Rinehart and Winston, Inc.

Fenneman, N. M. 1938. Physiography of Eastern United States. New York: McGraw-Hill Book Co.

Freeze, R. Allan and John A. Cherry. 1979. Groundwater. Englewood Cliffs, NJ: Prentice-Hall, Inc.

Johnson Division, UOP Inc. 1982. Groundwater and Wells. Saint Paul, Minnesota:

Johnston, Herbert E. 1985. Rhode Island Groundwater Resources. USGS Water Supply Paper 2275.

Lang, S. L. 1961. Appraisal of Groundwater Reservoir Areas in Rhode Island. Geological Bulletin 11.

Morrissey, Daniel J. 1987. Estimation of the Recharge Area Contributing Water to a Pumped Well in a Glacial-drift, River-valley Aquifer. USGS Open-file Report 86-543. Providence.

Myers, Jennie C. 1988. Governance of Nonpoint Source Inputs to Narragansett Bay: A Plan for Coordinated Action. Prepared for the Narragansett Bay Project/(Preliminary Draft).

Raghunath, H. M. 1987. Ground Water, 2nd ed. New York: John Wiley \& Sons.

Rhode Island Department of Administration/Division of Planning. 1988. Water Supply Policies for Rhode Island. Report $\$ 61$. Providence.

Rhode Island Department of Environmental Management/Office of Environmental Coordination. 1988. An assessment of Nonpoint Sources of Pollution to Rhode Island's Waters. Providence.

RI Office of Statewide Planning. 1986. Water Resource Issues in Land Use Policy. 
Todd, David Keith. 1976. Groundwater Hydrology, 2nd ed. New York: John Wiley \& Sons.

Todd, David Keith. 1980. Groundwater Hydrology, 2nd ed. New York: John Wiley \& Sons.

Todd, D. K. and D. E. Orren McNulty. 1976. Polluted Ground Water. NewYork: Water Information Centre Inc.

Tolman, C.F. 1937. Groundwater. New York: McGraw-Hill Book Company, Inc.

Walton, William G. 1970. Groundwater Resource Evaluation. New York: McGraw-Hill Book Company.

William, Peters S. 1987. Counting for something. New York: Springen-Verlag. 